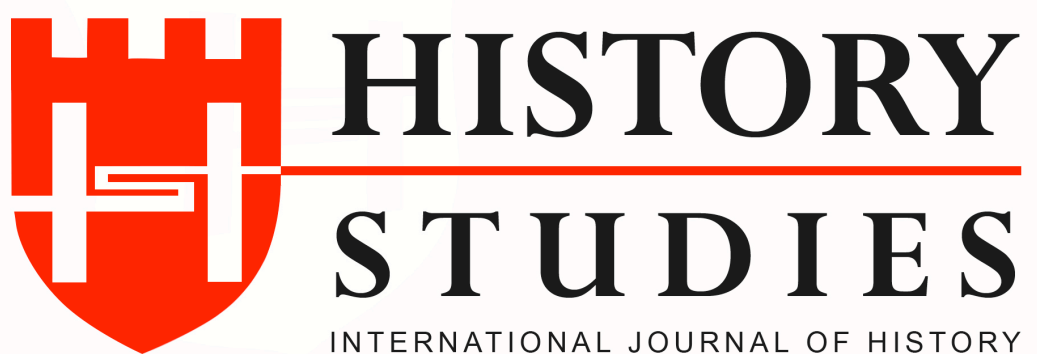

ISSN: 13094173 (Online) 1309 - 4688 (Print)

Volume 11 Issue 5, October 2019

DOI Number: 10.9737/hist.2019.786

Araştırma Makalesi

Makalenin Geliş Tarihi: 01.08.2019 Kabul Tarihi: 30.09.2019

Atıf Künyesi: Ramazan Sonat, “Bir Cephe İki Önemli Askerî Hata: Osmanlı Devleti Birinci Dünya Savaşı Sırasında Bağdat'ı Nasıl Kaybetti Sorusu Üzerine Düşünsel Bir Analiz”, History Studies, 11/5,

Ekim 2019, s. 1731-1751.

\title{
Bir Cephe İki Önemli Askerî Hata: Osmanlı Devleti Birinci Dünya Savaşı Strasında Bağdat'ı Nasıl Kaybetti Sorusu Üzerine Düşünsel Bir Analiz
}

\author{
One Front Two Major Military Mistakes: An Intellectual Analysis on the Question How \\ Did the Ottoman State Lost Baghdad during the First World War
}

\author{
Dr.Ramazan Sonat \\ ORCID No: 0000-0002-7189-5783 \\ Osmaniye Korkut Ata Üniversitesi
}

\begin{abstract}
Öz: Bu çalışma; Osmanlı Genelkurmayının Birinci Dünya Savaşı sırasında Irak'a yönelik askerîinisiyatiflerini muhakeme etmeyi amaçlamaktadır. Çalışma iki ana eksen üzerine inşa edilmiştir. Birinci kısımda, Osmanlı Genelkurmayının savaşın başlangıcında Irak'taki savaş konseptini nasıl algıladığı ve bu bağlamda ilgili alana hangi ordu birliklerini seferber ettiği tartışmaya açılmıştır. İkinci kısımda, Kut kuşatması sonrasında İran'a gönderilen 13'ncü Kolordu'nun merkezi Bağdat'ta yer alan 6'ncı Ordu'nun gücünü nasıl etkilediği ve onun Bağdat savunmasını ne şekilde zafiyete uğrattığı analiz edilmiştir. Sonuç kısmında ise iki olayın genel bir değerlendirmesi yapılarak bu olayların Osmanlı Devletinin Bağdat'ı kaybedişine hangi oranda tesir ettiği ortaya çıkarılmaya çalışılmıştır.
\end{abstract}

Anahtar Kelimeler: Osmanlı Genelkurmayı, Birinci Dünya Savaşı, Irak, Bağdat, 13'ncü Kolordu.

\begin{abstract}
This study aims to address the military initiatives of the Ottoman General Staff towards Iraq during the First World War. The study was built on two main axes. In the first part,it was discussed how the Ottoman General Staff perceived the concept of war in Iraq at the beginning of the war and in this context which army units mobilized the relevant area. In the second part, it was analyzed how the $13^{\text {th }}$ Corps sent to Iran after the siege of Kut affected the power of the $6^{\text {th }}$ Army in central Baghdad, and how it defeated the Baghdad defence. In conclusion, a general evaluation of the two events was made and it was tried to determine the extent to which these events affected the loss of Baghdad by the Ottoman Empire.
\end{abstract}

Keywords: Ottoman General Staff, First World War, Iraq, Baghdad, Thirteenth Corps.

\section{Giriş}

Osmanlı Devletinin Birinci Dünya Savaşı'na dahil oluş süreci kadar ${ }^{1}$ savaşı kaybedişi de tartışmalı bir konudur. Bilhassa son yıllarda savaşın yıl dönümü münasebetiyle Türkiye'de farklı disiplinlere mensup araştırmacılar tarafından gerçekleştirilen çalışmaların önemli bir kısmı bu meseleye odaklanmaktadır. Fakat bazı istisnalar dışında bu çalışmaların ortak özelliği

\footnotetext{
${ }^{1}$ Bu konuda yapılmış bazı özel çalışmalar için bkz: Mustafa Aksakal, Harb-i Umumi Eşiğinde Osmanlı Devleti Son Savaşına Nasıl Girdi?, İstanbul Bilgi Üniversitesi Yayınları, İstanbul 2010; Ali Kaşıyuğun, Osmanlı Devleti'nin I. Dünya Savaşı'na Girişi, Yeditepe Yayınevi, İstanbul 2015.
} 
ilgili konu hakkında kayda değer teoriler sunamamalarıdır. Hatta bunlar içerisinden bazıları Osmanlı Devletinin tecrübe ettiği bu başarısızlığı birtakım basmakalıp sebeplere dayandırmaktadır. Bu basmakalıp gerekçelerin en bilineni 1916 yılında Hicaz'da Şerif Hüseyin etrafinda şekillenen hareketin ${ }^{2}$ tüm Arap coğrafyasını temsil eden bir Arap ayaklanması ismi ile kamuoyuna takdim edilmesidir. Bu yönde hazırlanan çalışmalar ${ }^{3}$; Şerif'in Hicaz'da başlattığ 1 ayaklanmanın İstanbul'un daha önce Arap coğrafyasının değişik noktalarında karşılaştığı küçük ölçekli ayaklanmalardan pek bir farkı olmadığını ${ }^{4}$, ciddi derecede milliyetçi hislere rağmen savaş boyunca Osmanlı Ordusu içerisinde birçok Arap subayın yer aldığını ${ }^{5}$ ve Arapların ilgili süreçte bir taraf olmak yerine genel olarak kendi iç dinamiklerinin etkisiyle hareket ettiklerini görmezden gelmektedir ${ }^{6}$. Böylece bu çalışmalar temelsiz bir argüman üzerinden Osmanlı Ortadoğu'sunun elden çıkışını izah etmeye çalışarak tarihsel bir yanlışa imza atmaktadır. İkinci basmakalıp gerekçe Lawrence ve Gertrude Bell gibi birtakım simge isimlerin faaliyetlerini merkeze alarak Osmanlı Ortadoğu'sunun şekillendiğini iddia etmektir ${ }^{7}$. Her ne kadar ifade edilen kişiler savaş sırasında Osmanlı Ortadoğu'sundaki faaliyetleri ile kendi devletlerine çok ciddi derecede katkı sağlasalar bile savaşın gidişatına hiçbir şekilde doğrudan etki etmemişlerdir. Bu sebepten ifade edilen kişileri Osmanlı Ortadoğu'sunda meydana gelen gelişmelerin ana aktörleri olarak göstermek tarihsel gerçekliklerle bağdaşmamaktadır. Üçüncü büyük klişe Osmanlı Ordusu içerisinde yer alan Alman ve Türk subaylar arasında çeşitli konularda yaşanan anlaşmazlıkların Osmanlı Devletinin savaşma kabiliyetini ciddi anlamda

\footnotetext{
${ }^{2}$ Şerif Hüseyin isyanının nedenlerini konu edinen bir çalışma için bkz: M. Talha Çiçek, "İttihatçılar ve Şerif Hüseyin: Mekke İsyanının Nedenleri Üzerine Bir Değerlendirme’”, Tarih ve Toplum Yeni Yaklaşımlar, S. 16, (Yaz 2013), s. 41-57.

${ }^{3}$ İsmail Köse, Ingiliz Arşiv Belgelerinde Arap İsyanı, Kronik Kitap, İstanbul 2018; İsmail Köse, Büyük Oyun'un Küçük Aktörü Şerif Hüseyin, Kronik Kitap, İstanbul 2018; Recep Boztemur, “Arap İsyan1, 1916-1918', Mülkiye, C. XXXV, S. 272, (2011), s. 61-79. Bu çalışmalar, Şerif'in Hicaz'da başlattığı ayaklanma karşısında önde gelen Arap aşiretlerinin (Aneze, Şammar, Müntefik, Gazze, Tay vs.) nasıl pozisyon aldıklarını yeterince izah edememektedir. $\mathrm{Bu}$ durum da Şerif Hüseyin ismi ile Arap kimliğini tek bir pota içerisinde eritme kuramının geçerliliğini ciddi anlamda tartışmaya açan bir göstergedir. Arapların Birinci Dünya Savaşı öncesindeki ve sırasındaki konum ve yönelişlerini Şerif Hüseyin isminden bağımsız bir şekilde incelemek ilgili meselenin farklı bir boyutta tartışılmasına zemin hazırlayabilir. Bu konuyu analiz eden önemli bir çalışma için bkz: M. Talha Çiçek, "Erken Cumhuriyet Dönemi Ders Kitapları Çerçevesinde Türk Ulus Kimliği İnşası ve 'Arap İhaneti' ’, Divan, C. 17, S. 32, (2012/1), s. $169-188$.

${ }^{4}$ Kemal Karpat, Osmanlı'dan Günümüze Ortadoğu'da Millet, Milliyet, Milliyetçilik, Çev., Recep Boztemur, Timaş Yayınları, İstanbul 2011, s. 224-225.

${ }^{5} \mathrm{Bu}$ konuda yapılmış önemli bir çalışma için bkz: Mesut Uyar, “Ottoman Arap Officers between Nationalism and Loyalty during the First World War”, War in History, 20(4), (2013), s. 526-544. Burada ayrı bir parantez açmak gerekir. Hasan Kayalı'ya göre Arapçılığın Osmanlı Ordusu içerisinde popüler bir ideoloji olmasında Enver Paşa'nın 1914 kabinesinde hem müşirlik hem de harbiye nazırlığı görevine atanmasından sonra orduda başlattığı tasfiye hareketi oldukça etkili olmuştur. Yine Kayalı, Cemal Paşa'nın Suriye'deki faaliyetlerinin ordu içerisinde yer alan Arap subayları daha da radikalleştirdiğini ve bunlardan bir kısmının Şerif Hüseyin'in tarafına geçmesine sebep olduğunu çalışmasında önemle vurgulamıştır. Hasan Kayalı, Jön Türkler ve Araplar, Osmanlıcılık, Erken Arap Milliyetçiliği ve İslamcılık 1908-1918), Çev., Türkan Yöney, Tarih Vakfı Yurt Yayınları, İstanbul 2003, s. 201, 223224.

${ }^{6}$ Kayalı, Jön Türkler ve Araplar, s. 222-223, 237-238. Bu konuya örnek olması açısından hazırlanan bir çalışmada, ağırlıklı olarak Suriye ve Irak'ta meskûn olan El Aneze Aşireti'nin savaş sırasında Osmanlı ordu birliklerinin cephe hatlarına yönlendirilmeleri ile ilgili noktalarda kendisini nasıl konumlandırdığı üzerinde durulmuştur. Ramazan Sonat, "El Aneze Aşireti Ekseninde Birinci Dünya Savaşı’nın Gölgesinde Devlet-Aşiret İlişkisi ve Yansımaları Üzerine Bir Tarih Kritiği’’, History Studies International Journal of History, Vol., 10, Issue., 4, (June 2018), s. 167187.

${ }^{7}$ Özellikle Gertrude Bell son dönemde araştırmacıların yoğun bir şekilde ilgi gösterdiği bir sima olarak ön plana çıkmaktadır. Onu konu edinen çalışmalar ağırlık olarak Bell'in Lawrence gibi ‘Arap uyanışının' ortaya çıkışında ve Ortadoğu'nun şekillenmesinde aktif bir rol üstlendiğini iddia etmektedir. Bu konuda bazı kaynaklar için bkz: Kenan Karataş, Gertrude Bell İsyan, En Kitap Yayınları, İstanbul 2018; Taha Niyazi Karaca, Sinırları Çizen Kadın İngiliz Casus Gertrude Bell, Kronik Kitap, İstanbul 2018; Samet Yüce, Britanya’nın Ortadoğu Politikası ve Gertrude Bell, Nizamiye Akademi, İstanbul 2018.
} 
olumsuz etkilediğini öne sürmektir. Daha açık bir şekilde ifade etmek gerekirse ilgili konuyu ön plana çıkaranlar; Osmanlı Ordusu içerisinde görevli Alman subayların çoğunlukla yeterli donanıma sahip olmayan, kendi çalışma prensiplerini Türk subaylara kabul ettirmeye çalışan kişilerden oluştuğunu ve bu durumun emir komuta zinciri ile buna bağl1 olarak birliklerin harekât kabiliyetini etkisizleştirdiğini önemle vurgulamaktadır ${ }^{8}$. Fakat ilgili görüşün Türk bilim camiasının tamamını temsil etmediğini aksine bazı uzmanların son yıllarda yaptıkları çalışmalar ile bu klasik söylemi çeşitli yönlerden eleştiriye tâbi tuttuklarını söylemek mümkündür? .

Osmanlı Devletinin Birinci Dünya Savaşı'nı kaybedişini izah etmek için dile getirilen bu basmakalıp gerekçeleri çoğaltmak mümkündür. Fakat bunların hiçbiri Osmanlı Genelkurmayının savaşın değişik alanlarına yönelik hatalı inisiyatiflerinin önüne geçebilecek argümanlar değildir. Zira Osmanlı Genelkurmayı savaş boyunca hem sahip olduğu kısıtlı insan gücün ̈̈ ${ }^{10}$ doğru kullanamayarak hem de bir dizi stratejik hatalar yaparak başarısızlı̆̆ın oluşmasında baş rol oynamıştır. Ancak onun başarısızlığın oluşumuna ne şekilde tesir ettiğini konu edinen akademik çalışma sayısı yok denecek kadar azdır ${ }^{11}$. İlgili sebepten bu çalışmada mevcut eksikliği giderebilmek için Osmanlı Genelkurmayının Irak Cephesi'ndeki hatalı inisiyatifleri ve bu inisiyatiflerin sebep olduğu sonuçlar ortaya çıkarılmaya çalışılmıştır. Bu kapsamda çalışma iki ana başlık üzerine inşa edilmiştir. Birinci başlıkta; Osmanlı

HISTORY STUDIES

1733

Volume 11

Issue 5

October

2019

${ }^{8}$ Bu konuda bazı kaynaklar için bkz: İsmet Üzen, "Birinci Dünya Savaşında Sina ve Filistin Cephesindeki TürkAlman Subayların Çeşitli Konularda Çatışması (1914-1918)', Karatekin Edebiyat Fakültesi Dergisi, C. 3, S. 3, (2014), s. 77-100; Uğur Üçüncü, “'Birinci Dünya Savaşı'nda Mustafa Kemal Paşa’nın Osmanlı Ordusu'ndaki Alman Subaylarına Bakışı”, OTAM, 39, (Bahar 2016), s. 251-vd; Hayati Aktaş, “Birinci Dünya Savaşı'nda Türkiye'de Görev Yapan Alman Subaylarının Faaliyetlerinin Bir Değerlendirmesi ve Türk Askerinin Konumu', History Studies International Journal of History, Vol., 11, Issue., 2, (April 2019), s. 469-482.

${ }^{9}$ Örneğin Gültekin Yıldız hazırladığı çalışmada (Gültekin Yıldız, "Birleşik Harekât Tecrübesi Olarak Cihan Harbinde Türk-Alman Askerî İttifakı', 1914'ten 2014'e 100'üncü Yılında Birinci Dünya Savaşı'nı Anlamak, Harp Akademileri Komutanlığ 1 Stratejik Araştırmalar Enstitüsü, İstanbul 2014, s. 191-202) klasik söylemden bağımsız bir şekilde Birinci Dünya Savaşı sırasındaki Türk-Alman askerî ittifakının mahiyetini multidisipliner bir bakış açısıyla ortaya koymuştur.

${ }^{10}$ Osmanlı Devletinin dört yıl boyunca seferber ettiği asker sayısı İtilaf ve İttifak blokunun diğer üyeleri ile karşılaştırıldığında oldukça düşük bir rakamdır. Onun seferber ettiği iki milyon sekiz yüz elli bin askere karşın Rusya on iki milyon, Almanya on bir milyon, İngiltere yaklaşık dokuz milyon, Fransa yaklaşık sekiz buçuk milyon, Avusturya-Macaristan ise yaklaşı sekiz milyon askeri seferber hale getirmiştir. https://www.britannica.com/event/World-War-I/Killed-wounded-and-missing. $\quad$ Erişim Tarihi: 25.02.2019.http://www.uwosh.edu/faculty_staff/henson/188/WWI_Casualties\%20and\%20Deaths\%20\%20PBS.html. Erişim Tarihi: 25.02.2019.

${ }^{11}$ En başta şunu ifade etmek gerekir ki bu konuda yeterince müstakil çalışma olmayıșı tarafımızdan ciddi bir eksiklik olarak değerlendirilmektedir. Fakat son yıllarda savaşın yıl dönümü münasebeti ile konunun uzmanları tarafindan yapılan farklı değerlendirmeler/açıklamalar bu açı̆̆ı kapatmaya yöneliktir. Örneğin Mesut Uyar mesele ile alakalı şu değerlendirmeyi yapmıştır: "Osmanlı bir ittifakın küçük üyesi olarak savaşa girdi. Dolayısıyla savaşın kaderi üzerinde etkisi sınırlıydl. Nihai yenilgi tartışmasını Almanya üzerinden yapmak gerekir. Askeri imkânları tartı̧̧aya hiç gerek yok. Ortaçağdan kalma tarım ekonomisi ve toplumsal düzenine sahip olan fakir bir devletin endüstriyel topyekûn uzun bir savaşta başarılı olmasını beklemek bence hatalı olur. Zaten savaşın uzun süreceği tahmin edilseydi Osmanlı'yı kimse savaşa sokamazdl. Şaşırtıcı olan imparatorluğun bu kadar uzun ve büyük ölçüde başarıyla dayanabilmesidir. Ben bunun arkasında 1826'dan beri sürdürülen askeri reformları görüyorum. Ayrıca imparatorluk ciddi ölçüde vatandaşlarını entegre edebilmiştir ki bu kadar uzun süre ordu ve halk dayanmıştır. Tabii farklı eyaletlerde farklı resimlerle karşılaşıyoruz. Bu uzun dayanmanın ă̆ır bir bedeli olmuş imparatorluk meşruiyetini savaşın sonunda büyük ölçüde kaybetmiştir'. Gültekin Yıldız ise konu ile alakalı şöyle bir değerlendirme yapmıştır: "Henüz Çanakkale Cephesi hakkında dahi, harp ceridelerine dayal, tetkiklerin yeterli miktar ve kalitede olmadiğını söylersek; Cihan Harbi’nde Osmanlı ordusunun etkinliğini farkl parametrelerle değerlendirmenin hâlâ zor olduğu ortaya çıkacaktır. Bununla beraber, mevcut literatür ışı̆̆ında, savaşın kaybında en önemli ü sebep olarak, lojistik altyapısının eksikliği, Osmanlı ekonomisi ve insan kaynağının yetersizliği ve her cephede Türk-Alman ittifakının arazide iyi işlememesini sayabilirim". Röportaj: "Osmanlı Savaşı Neden Kaybetti?'”, Atlas Tarih, Dosya Editörü: Tuncay Y1lmazer, S. 56, (Aralık 2018-Ocak 2019), s. 104-105.

\section{History Studies}


Genelkurmayının savaşın başlangıcında Irak'taki ${ }^{12}$ savaş konseptini nasıl algıladı̆̆ı, buna göre bu alana hangi ordu birliklerinin mobilizasyonunu gerçekleştirdiği ve bunları ne şekilde kullandığı üzerinde durulmuştur. İkinci başlıkta ise Kut kuşatması sonrasında İran'a gönderilen bazı Osmanlı ordu birliklerinin merkezi Bağdat'ta yer alan 6'ncı Ordu'nun gücünü nasıl etkilediği ve buna bağlı olarak onun Bağdat savunmasında nasıl bir zafiyete sebebiyet verdiği tartışılmaya açılmıştır. Çalışmada bütün bu olgular ağırlıklı olarak Türk ve Alman subayların beyanatları ekseninde irdelenmeye çalışılmıştır. Bir anlamda çalışma iki müttefik devletin sahadaki uyuşmazlığını, alanı kaplama noktasındaki yetersizliğini ve bu durumun sebep olduğu sonuçları tarafları temsil eden isimler üzerinden açıklamayı tercih etmiştir. Ayrıca çalışmada konu ile ilgili bugüne kadar yapılan bütün çalışmaları derleyip onları belirli bir süzgeçten geçirdikten sonra meseleyi daha düşünsel bir zemine oturtmak amaçlandığ 1 için arşiv malzemeleri kullanılmamıştır. Bu durum da çalışmanın derleme türünün bir örneğini temsil ettiği gerçeğini okuyucunun hiçbir zaman göz ardı etmemesi gerektiğini ön plana çıkarmıştır.

\section{Osmanlı Genelkurmayının Savaşın Başlangıcında Irak'taki Savaş Konseptini Algılayış Biçimi ve Bu Durumun Onun Harp Kabiliyetine Etkisi}

1914 yılının yaz ayları içerisinde Avrupa'da savaş rüzgarlarının esmeye başlaması Osmanlı sınırları dahilinde yer alan ordu birliklerinin yeniden yapılandırılmalarını zaruri bir hale getirmiştir $^{13}$. Bu kapsamda; bir taraftan birliklerin eleman, teçhizat ve lojistik açılardan eksiklikleri giderilirken diğer taraftan da onların öncelikli savaş alanlarına göre konumlandırılmaları gerçekleştirilmeye başlanmıştır ${ }^{14}$.

Osmanlı Genelkurmayının Irak'a atfettiği stratejik değer, devam eden süreçte ordu birliklerinin bu alana konumlandırılmalarını doğrudan etkileyen en önemli faktör olarak ortaya çıkmıştır. Şöyle ki 1914 Ağustosunda Irak'ın askerî yapısını, 6'ncı Ordu dışında Musul'da yer alan 12'nci Kolordu ile Bağdat'ta bulunan 13'ncü Kolordu oluşturmuştur. Fakat Osmanlı Genelkurmayının birtakım istihbari bilgiler doğrultusunda bu alanda İngiltere ile yoğun bir harbe girilmesini öngörmemesi üzerine Irak'ta yer alan birlikler eylül ayı itibariyle öncelikli savaş alanlarına doğru kaydırılmaya başlanmıştır. Osmanlı Genelkurmayının hazırladığı seferberlik planı ve onu hayata geçirebilmek için oluşturulan yığınak planı çerçevesinde 13'ncü Kolordu 3'ncü Ordu'yu desteklemek maksadıyla kuzeye doğru kaydırılırken 12'nci Kolordu ise Şam'da konuşlanan ve Mısır'a taarruz için hazırlıklara başlayan 4'ncü Ordu'nun emri altına verilmiştir. Buna mukabil askerî açıdan boşaltılan Irak coğrafyası da bölge komutanlığı halini $\operatorname{almıştır~}^{15}$.

Irak coğrafyasının askerî açıdan boşaltılması işlemi Osmanlı Devletinin fiilen savaşa dahil olduğu kasım ayına kadar devam etmiştir. Kasım ayına gelindiğinde ise Irak coğrafyası sadece Irak Bölge Komutanlığına bağlı ve yeni yeni oluşturulmaya başlanan ağılıklı olarak tam

\footnotetext{
${ }^{12} \mathrm{Bu}$ kavramdan kasıt Bağdat, Basra ve Musul'u kapsayan alandır. Esasında bu üç nokta Dicle ve Fırat nehirleri arasında kalmaları sebebiyle bilimsel çalışmalarda daha çok Mezopotamya kavramı içerisinde işlenmektedir. Fakat bu makalede Mezopotamya kavramı yerine Osmanlı Genelkurmayının ilgili noktaları tanımlamak için kullandığı Irak kavramı tercih edilmiştir.

${ }^{13}$ Esasında bu teşebbüsün Balkan Savaşları sonrasında orduda görülen belirgin değişimin devamı niteliğinde olduğunu söylemek mümkündür. Osmanlı Ordusu'nun Balkan Savaşları ile birlikte geçirdiği dönüşüm için bkz: Mesut Uyar-Edward J. Erickson, Osmanlı Askeri Tarihi, İş Bankası Kültür Yayınları, İstanbul 2017, s. 469-483.

${ }^{14}$ Edward J. Erickson, Size Ölmeyi Emrediyorum! Birinci Dünya Savaşı’nda Osmanlı Ordusu, Çev., Mehmet Tanju Akad, Kitap Yayınevi, İstanbul 2011, s. 25-28, 63-75.

${ }^{15}$ Cemalettin Taşkıran, Ana Ben Ölmedim, Birinci Dünya Savaşı'nda Türk Esirleri, Türkiye İş Bankası Kültür Yayınları, İstanbul 2015, s. 41; Erickson, Size Ölmeyi Emrediyorum!, s. 62-70, 95-96.
} 
anlamıyla disipline edilmemiş yerel unsurlardan müteşekkil 38'nci Piyade Tümeni tarafından tahkim edilmeye çalışılmıştır ${ }^{16}$.

Irak coğrafyasının tahkimatının arttırılmak bir yana kolordu seviyesinden tümene indirilmesi devletin bu alandaki harp kabiliyetini doğrudan etkileyen en önemli faktör olarak ortaya çıkmıştır. Zira Osmanlı Genelkurmayının diğer harp alanları ile karşılaștırıldığında Irak'ta daha düşük seviyede bir muharebeyi öngermesi ve ilgili vaziyete göre hazırlıklarını gerçekleştirmesi İngiltere'nin bu alana ciddi manada yoğunlaşmasının önünü açmıştır. Türk Ordusu'nun genel durumunu ve buna bağlı olarak Irak'taki mevcudiyetini istihbarat raporları ekseninde oldukça zayıf bulan İngiltere ${ }^{17} 1914$ yılının başından itibaren daha fazla bölgeye yönelik askerî taktik ve stratejiler geliştirmeye başlamıştır. Fakat aynı süreçte İngiliz istihbaratının birleşik bir yapıda olmaması taktik ve stratejilerin hayata geçirilmesini zorlaştıran etken olarak ön plana çıkmışıtır. Bu durum karşısında nasıl ki Sina Yarımadası ve Akdeniz Bölgesi hakkında Mısır'da bulunan savaş ofisinden ve Kafkasya hakkında Ruslardan bilgi temin ediliyorsa Irak için de Bağdat ve Basra'da yer alan konsolosluk görevlilerinden istihbarat elde edilme yoluna gidilmiştir. Nitekim edinilen istihbarat çerçevesinde Türklerin Bağdat'taki askerî mevcudiyeti yaklaşık on beş bin kişi olarak tespit edilirken Basra'daki bin iki yüz kişi olarak belirlenmiştir. Ayrıca Irak'ta yer alan Türk birlikleri genel hatları ile düzensiz ve yeterli eğitime tâbi tutulmamış unsurlar olarak algılanmıştır ${ }^{18}$.

Edinilen istihbarat raporları ekseninde Irak coğrafyasının zayıf Türk birlikleri tarafindan çevrelenmesi hali hazırda Basra Körfezi ve civarında askerî mevcudiyeti bulunan İngiltere'nin bu mevcudiyetini daha ileri noktalara taşımasına olanak sağlamıştır. Bilhassa Almanya'nın kontrolü altında olan Osmanlı Devletinin ${ }^{19}$ ilan edeceği muhtemel Cihâd-1 Ekber'in tüm Arap coğrafyasını ve Afganistan, Pakistan ve Hindistan'ı derin bir şekilde etkileyeceğini düşünen İngiltere Basra'yı kendisine hedef olarak saptamıştır. Nitekim 1914 Kasımının ilk günlerinde tarafların fiili olarak birbirlerine harp ilan etmeleri ile Basra'nın işgaline giden süreç başlamıştır ${ }^{20}$.

Savaşın henüz fiili olarak başlamasından önce Türk birliklerinin ağılıklı olarak Doğu'da Ruslara karşı Kafkas Cephesi'nde- konuşlandığını ${ }^{21}$ ve Irak’ta yalnızca tek bir düzenli askerî

\footnotetext{
${ }^{16}$ Erickson, Size Ölmeyi Emrediyorum!, s. 70, 96.

${ }^{17}$ Esasında Balkan Savaşları ile birlikte Türk Ordusu'nun genel durumunu İstanbul ve Atina'daki ataşelerinin raporları vasıtasıyla yakından takip etmiştir. Nitekim elde edilen raporlar çerçevesinde, İngiltere tarafından hem Türk Ordusu'nun savaşma kabiliyeti ilerisi için yetersiz bulunmuş hem de ordu içerisinde ciddi derecede Alman nüfuzu olduğu kanaatine varılmıştır. Richard Popplewell, “British intelligence in Mesopotamia 1914-1916”, Intelligence and National Security, 5:2, (1990), s. 139-141.

${ }^{18}$ Popplewell, "British intelligence", s. 141-144.

${ }^{19}$ Özellikle savaş öncesinde Osmanlı Ordusu içerisinde görevli Alman subayların etkinliği İngiltere'nin yakından takip ettiği bir konudur. Popplewell, "British intelligence”, s. 140-141. Ayrıca Almanya'nın Bağdat Demiryolu projesi ve çeşitli ticari meseleler ile Osmanlı Devletinden imtiyazlar elde etmesi savaşa giden süreçte İngiliz-Alman gerginliğini had safhaya çıkaran diğer gelişmeler olarak ortaya çıkmıştır. Bu konuda bkz: H. Bayram Soy, "Birinci Dünya Savaşı Öncesinde 'Orta Doğu'da' Alman-İngiliz Mücadelesi’, Türkiye Günlüğü, S. 81, (Yaz 2005), s. 104117.

${ }^{20}$ Peter Sluglett, "An improvement on colonialism? The 'A' mandates and their legacy in the Middle East", International Affairs, 90:2, (2014), s.414-415; Kristian Coates Ulrichsen, "The British Occupation of Mesopotamia, 1914-1922”, The Journal of Strategic Studies, Vol., 30, No., 2, (April 2007), s. 350; Victoria Whitecotton, “The Iraqi Mandate: An Examination of the Relationship between Britain and Iraq in the Aftermath of the First World War, Saber and Scroll, Vol., 1, Issue., 3, Article 7, (Fall 2012), s. 66; Lieutenant Colonel P. T. Crowley British Army, "Operational Lessons of the Mesopotamia Campaign, 1914-1918', Defence Studies, Vol., 4, No., 3, (Autumn 2004), s. 336; Popplewell, “British intelligence”, s. 143-145.

${ }^{21}$ Osmanlı Genelkurmayının savaş sırasında ciddi sayıda Türk birliğini Doğu'da -Kafkas Cephesi’ndekonuşlandırmasında Almanya'nın rolü büyüktür. Bu durum Almanya'nın Kafkasya politikasını İstanbul üzerinden tatbik etme arzusu ile açıklanabilir. Nitekim Mustafa Çolak konu hakkında şöyle bir değerlendirme
}

\section{History Studies}


birliğin yer aldığını tespit eden İngiltere, Hindistan'da yer alan kuvvetleri ile kasım ayının ilk günlerinde Basra'ya çıkarma harekâtını başlatmıştır. Fakat bu teşebbüs ilk etapta yeterli istihbari bilgiler ile desteklenemediği için aynı süreçte Hindistan (Delhi) merkezli ${ }^{22}$ başlatılan harekâtın seyri konusunda birtakım belirsizlerin ortaya çıkmasına neden olmuştur. Fakat kısa süre içerisinde hem bölgesel kaynaklardan -bilhassa Muhammara ${ }^{23}$ - hem de savaş esirlerinden edinilen bilgiler doğrultusunda Türklerin Basra ve civarında daha fazla mukavemet edebilecek güçleri olmadığı anlaşılmıştır. Bunun sonucu olarak da İngiliz kuvvetlerinin Basra'yı işgali kasım ayının son günlerine doğru gerçekleşmiştir ${ }^{24}$.

İngiliz kuvvetlerinin Basra’yı işgali ve akabinde iç kısımlara doğru ilerleyişi Osmanlı Genelkurmayının Irak'a yönelik askerî fikriyatını derinden sarsmışı̧ı. Bu sürece gelinceye kadar Irak coğrafyasını âtıl bir nokta olarak tanımlayan ve kendisine göre savaşın ağırlık merkezini başka alanlar olarak belirleyen Osmanlı Genelkurmayı artık Irak'a yönelik İngiliz tehdidini nasıl ortadan kaldıracağını analiz etmeye başlamıştır. Fakat aralık ayı içerisinde Kurna'nın düşmesi, İngilizlere karşı mücadele veren 38'nci Piyade Tümeni'nin dağılması ve ondan kalan unsurların Amâre yönüne doğru çekilmesi tehlikenin boyutunun daha da genişlemesine neden olmuştur ${ }^{25}$.

Irak’taki güç dengesinin yavaş yavaş İngilizlere doğru kaymaya başlaması bölgeye yönelik mevcut savaş konseptininin artık geçerliliğini yitirdiğini ortaya koymuştur. Bunun üzerine Osmanlı Genelkurmayı Irak'a yönelik yeni bir harp fikriyatı oluşturarak bunun tatbik edilebilmesi için Süleyman Askeri Bey' $i^{26}$ Ocak 1915 tarihinde bölgeye gönderme kararı almıştır. Arkasından da takviye kuvvetler ile yeniden düzenlediği 38'nci Piyade Tümeni'ne ek

gerçekleştirmiştir: “Almanya'nın Kafkas halklarını Ruslara karşı isyana tahrik ve teşvik faaliyetlerinde başarılı olması, Osmanl Devleti'nin Kafkas cephesinde başarılı olmasıla doğru orantılı idi. Müttefik Osmanlı Devleti coğrafi olarak Kafkasya'ya ne kadar yakın olursa, Almanya'nın Kafkasya'ya sağlayacağ silah ve lojistik destek de o kadar kolay olacaktı. Öte yandan Osmanl Devleti'nin Kafkas Cephesi'nde belli miktarda Rus ordusu tutmasi, Almanya karşısındaki Rus ordusu sayısında azalma meydana getireceği için, Alman doğu cephesinde daha rahat hareket edebilecekti'. Mustafa Çolak, Alman İmparatorluğu'nun Doğu Siyaseti Çerçevesinde Kafkasya Politikası (1914-1918), Türk Tarih Kurumu Yayınları, Ankara 2006, s. 108.

${ }^{22}$ Burada ayrı bir parantez açmak gerekir. İngiltere'nin Birinci Dünya Savaşı sırasında Irak coğrafyasına yönelik askeri teşebbüsleri iki merkez üzerinden dizayn edilmiştir. 1914 Kasımından Kut kuşatmasına kadar geçen süre içerisinde Irak harekâtı ağırlıklı olarak Delhi Hükümeti tarafından yönetilmiştir. Fakat İngiliz birliklerinin Kut’ta yaşadıkları başarısızlığın ardından Londra (Westminster Hükümeti) kamuoyunun da etkisiyle Irak harekâtının sorumluluğunu tamamen üzerine alarak Delhi’yi devre dışı bırakmıştır. Bu konuda hazırlanan bir çalışma için bkz: Ramazan Sonat, “İki Farklı Hükümet İki Farklı Yaklaşım: İngiltere'nin Birinci Dünya Savaş1 Sırasında Mezopotamya Harekâtının Şekillenmesinde Londra ve Delhi'nin Rolü ve Kut'ül Amâre Meselesine Yönelik Yeni Yaklaşımlar", Çanakkale Araştırmaları Türk Yıllı̆̆ı, Y1l 17, S. 26, (Bahar 2019), s. 71-84.

${ }^{23}$ Muhammara, Basra'nın yaklaşık otuz sekiz kilometre güneydoğusunda, İran'ın Arabistan Eyaleti sınırları içerisinde yer alan bir yerleşim alanıdır. İngiltere'nin XIX. yüzyılın ikinci yarısından itibaren Basra Körfezi ve civarında etkinliğini arttırması Muhammara ile yakın ilişkiler geliştirmesini sağlamıştır. Nitekim geliştirilen bu ikili ilişki sayesinde hem savaş öncesinde hem de savaş sırasında Muhammara'dan elde edilen istihbarat İngiliz askerî harekâtının tatbik edilmesine katkı sağlamıştır. Rumbeyoğlu Fahreddîn-Mehmed Nâbî, 'Osmanlı Devleti'nin Son Yıllarında Dış Politika Meseleleri IV: Muhammere”, Tarih Okulu Dergisi, Aktaran., Ünal Taşkın, XIX (7), (Eylül 2014), s. 837; M. H. Donohoe, Ingiltere'nin Iran/Azerbaycan Seferi 1918, Çev., Cengiz İ. Çay, Tarih ve Kuram Yayınları, İstanbul 2016, s. 39; The National Archives, Foreign Office, Annual Report 1912, 416/111, s. 22-26. Bundan sonraki kullanımlarda bu arşiv tasnifi (TNA. FO.) olarak kısaltılmıştır; TNA. FO., Annual Report 1911, 416/111, s. 35-36; TNA. FO., Annual Report 1910, 416/111, s. 25-30; Popplewell, “British intelligence”, s. 145.

${ }^{24}$ Popplewell, "British intelligence", s. 145.

${ }^{25}$ Erickson, Size Ölmeyi Emrediyorum!, s. 98.

${ }^{26}$ Onun bu göreve tayin edilmesinde daha önce Bağdat'ta görev yapması, Libya mücadelesi içerisinde yer alması ve Teşkilat-1 Mahsusa'nın en tepesine kadar yükselebilmesi önemli rol oynamıştır. Orhan Koloğlu, Curnalcilikten Teşkilat-ı Mahsusa'ya, Kırmızı Kedi Yayınevi, İstanbul 2017, s. 114.

\section{History Studies}


olarak Eylül ayı içerisinde Halep'e doğru gönderdiği 35'nci Piyade Tümeni'ni ocak ayı içerisinde Irak'a yeniden sevk etmiştir ${ }^{27}$.

Osmanlı Genelkurmayının yeni harp konsepti çerçevesinde Süleyman Askeri Bey'i Irak'ta yer alan kuvvetlerin komutanı olarak tayin etmesi her ne kadar savunma anlayışına bir nebze canlılık sağlasa da İngiliz kuvvetlerinin ilerleyişini engelleyememiştir. Osmanlı Genelkurmayının ilk etapta oluşturduğu savaş konsepti sayesinde Irak'ın askerî anlamda boşaltılmasını iyi değerlendiren İngiliz kuvvetleri hali hazırda Basra ve civarında yerleşik bir hal alarak bölgede kalıcı bir güç olarak ortaya çıkmıştır. Nitekim 1915 yılının bahar ayları içerisinde Süleyman Askeri Bey'in komutası altında bulunan Türk birlikleri ile İngiliz kuvvetleri arasında meydana gelen muharebelerin İngilizler lehine sonuçlanması var olan durumu pekiştirmiştir. Ayrıca gelinen nokta Bağdat'a doğru gerçekleşecek İngiliz ilerleyişinin de bir anlamda yapıtaşını oluşturmuştur ${ }^{28}$.

Osmanlı Genelkurmayının savaşın ilk safhalarında Irak coğrafyasını savunmasız bir şekilde bırakması ve İngiliz işgaline açık hale getirmesi birçok açıdan tartışmalı bir konu olarak ön plana çıkmaktadır. Tartışmanın temelinde, alınan bu kararın zorunluluktan mı kaynaklandığ veyahut ihmalkarlıktan $\mathrm{m} 1$ ortaya çıktığı yer almaktadır. Ayrıca Osmanlı Ordusu içerisinde ciddi bir nüfuza sahip Alman subayların bu kararın oluşmasına ne şekilde sirayet ettikleri ve kararı nasıl karşıladıkları bir diğer belirsiz meseledir. Bu sebepten savaş sırasında Osmanlı Ordusu'nun çeşitli kademelerinde görev yapmış olan Türk ve Alman subayların veyahut Osmanlı sınırları dahilinde bulunmuş birtakım konsolosluk çalışanlarının anılarında dile getirdikleri görüşler meselenin açığa kavuşturulması açısından oldukça önemlidir. Nitekim bu konuya 1şık tutması bakımından savaş sırasında 2'nci Ordu ve Kafkas Cephesi Genel Komutanlığı vazifelerini ifâ eden Ahmet İzzet Paşa'nın ${ }^{29}$ anılarında dile getirdiği şu değerlendirmeler oldukça ilginçtir:

“4. Ordu Müfettişliği’ne bă̆ll olan 13. Băgdat ve 12. Musul Kolordularl ikişer tümenliydi. Seferberlik başlarında 13. Băgdat Kolordusu, 3. Erzurum ve 12. Musul Kolordusu, 4. Suriye Ordularına tahsis olundu. Daha sonra yapılan itirazlar üzerine yalnız 38. Tümen Irak'ta bırakılmış fakat bunun alayları da üçer tabura tamamlanmayarak toplam altı taburdan ibaret kalmıştır. Bu önlemlerin 'kudam gılzet rû tashih künem ey hâne harap' sözünden başka eleştiriye değecek yönü yoktur. Basit bir düşünceyle görülüyor ki, Musul havalisi Erzurum'a daha yakındır. Halk nispeten daha kuzeyli ve büyük kısmı Kürt ve Türk ırkından ve dağll olup 3. Ordu iklimine hiç olmazsa Băgdat ve Basra civart ahalisinden biraz daha fazla mukavemet edebilir. Bunlarl llıman ve kismen de sicak bölgelerden olan Suriye'ye, sonra Băgdat ve Basra tümenlerini kış kıyamette iki katı mesafe katettirerek Kuzey Kutbu'na rahmet okutan Erzurum bölgesine göndermek, bilmem ne gibi sebep ve düşüncelere dayandirllabilir.

Suriye'ye Bă̆dat, Musul'dan fazla uzak değildir. Băgdat askerinden kuzey Bölgelerinde yararlanılamayacağına dair tarihî örnekler de vardır. Sonra Irak'ın böyle bir zamanda askerden boşaltılmasından daha büyük bir hata düşünülemez. Irak'ta öteden beri Ingilizlerin ihtiraslar olduğunu bilmeyen çocuk bile yoktur. Irak ve Mezopotamya'nın kültür ve medeniyet tarihi, iyi idare ve kullanma halinde feyz ve bereketinin Nil, Pencap, Sind, Ganj havzalarına taş çıkartacă̆ı hakkındaki şöhreti dolayısıyla sahibi ve tasarrufçusu için büyük bir klymete sahip ve istilâcı bir büyük devlet için hırs ve iştihayı

\footnotetext{
${ }^{27}$ Joseph Pomiankowski, Osmanlı İmparatorluğunun Çöküşü, Ter., Kemal Turan, Kayıhan Yayınları, İstanbul 2014, s. 98, 157; Erickson, Size Ölmeyi Emrediyorum!, s. 98.

${ }^{28}$ Irak Cephesi'nden Burma'ya Savaşın ve Esaretin Günlüğ̈̈, Taşköprülü Mehmed Efendi, Haz., Mesut Uyar-Ahmet Özcan, Türkiye İş Bankası Yayınları, İstanbul 2015, s. 10-11; Erickson, Size Ölmeyi Emrediyorum!, s. 150-151.

${ }^{29}$ Ahmet İzzet Paşa, Feryadım, İstiklâl Harbi’nin Gerçekleri, Yay. Haz., Süheyl İzzet Furgaç-Yüksel Kanar, C. 1, Timaş Yayınları, İstanbul 2017, s. 265-266, 292.
} 
kabartıp tahrik ettiği apaçık bilinen gerçeklerdendi. Müslümanlar ve özellikle Şia gözünde çok kutsal sayılan mekânları, yüksek mertebeleri Sünnilerce mukaddes olan İmam-l Azam türbesi ve Hint Müslümanlarının fevkâlade sevgi besledikleri ve bağlı oldukları Abdülkadir Geylânî'nin kabir ve muhterem ailelerinin bulunduklarl yerleri içine alan Irak'a sahiplenmek, birçok İslâm tebaasına sahip olan Hicaz'a da koruyuculuk edeceğini düşünen İngiltere'nin İslâm siyaseti için ne kadar faydalı ve arzuya şayan olacağı kolayca takdir edilebilirdi. Bu sebepler, fütuhatçı ihtiraslarından başka, Irak'ın coğrafi konumu bakımından Hint'e karşı güçlü bir hasım elinde, gelecek için bir tehdit sebebi olabileceğinden dolayl, Ingiltere'nin koruma ve savunma düşüncesiyle de savaş sirasında buraya göz dikmesi doğaldı. Bahreyn adalarını hatta ve Mahmera'yl hareket üssü kabul etmek ve çevre sömürgelerinden birkaç günde asker getirebilecek mevki ve kuvvette olan İniltere'ye karşı bu kitayı mahallî kuvvetlerinden ayırmak, bu hükümeti, mülkümüzü istilayya hırslandırmak ve davet etmekten başka bir şey değildir. Bilmem bu kadar kaba bir hata neye yüklenmeli, nasll nitelenmeli? , 30

Ahmet İzzet Paşa'nın görüşlerinin bir benzeri 1909-1918 tarihleri arasında AvusturyaMacaristan İmparatorluğu'nun İstanbul'daki büyükelçiliğinde askeri ataşe olarak görev yapan General J. Pomiankowski ${ }^{31}$ de paylaşmıştır. Nitekim onun: 'Enver Paşa'nın, İngilizlerin Basra Körfez'inde karaya çıtkmasına ve Irak'a karşı bir saldırıyı Kerkük üzerinden başlatmayıp bilakis bu vilayetin birliklerden tecrit edilmesine inanması telafisi güç bir hata olarak kabul edilmekteydi, ${ }^{32}$ minvalindeki sözleri bu kapsamda değerlendirilebilir. Ayrıca Pomiankowski, anılarında konu ile alakalı “'Birliklerden tamamen tecrit edilmiş olan Irak'ta harekâtın başlaması, haliyle çok ters yönde şekil almıştı" "33 şeklinde bir başka yorum daha yapmıştır.

Seferberlik sırasında genelkurmayda görevli olan ve ordu birliklerinin dağıtımına bizatihi şahit olan Ali İhsan Paşa ise anılarında Irak'a yönelik alınan askerî inisiyatifi daha kapsamlı bir şekilde ele almıştır. En başta Ali İhsan Paşa, seferberliğin ilanı ile birlikte Irak'ta yer alan birliklerin diğer savaş alanlarına kaydırılmasına soğuk bakmıştır. Bu durumun temel sebebi olarak da Irak coğrafyasının hali hazırda merkezi otoriteden bağımsız bir şekilde hareket eden aşiret yapılanmalarına ve isyancılara sahip olduğunu ve birliklerin ayrılması halinde onların kolay kolay dizginlenemeyeceğini düşünmüştür. Nitekim bu görüşünü Alman subayların anlayamamasını, Almanların hiçbir zaman ordusunu kendi sınırları içerisinde kullanmaya ihtiyaç duymamış olması ile açıklamıştır. Fakat Ali İhsan Paşa'nın bu fikrine rağmen başını Bronsart Paşa'nın çektiği Alman komuta kademesi ve onlar ile aynı görüşü paylaşan Türk subaylar Irak'ta yer alan birliklerin başka noktalara kaydırılması hususunda bir görüşü benimsemeyi sürdürmüşlerdir ${ }^{34}$. Bu konu kapsamında Ali İhsan Paşa; kendisi, Bronsart Paşa ve Hakkı Paşa arasında genelkurmayda yapılan görüşmeyi anılarında şu temsili sözler ile açıklamıştır:

"Bronzart Paşa, Hafiz Hakkı'nın fikrini sordu. O da 'şimdilik bu kadar kâfidir' dedi. Bunun üzerine Bronzart Paşa, bir dakika kadar düşündükten ve haritaya baktıktan sonra 'Irak'ta fazla kuvvet bırakılması muvafik değildir; yalnız Basra'daki 38 inci firkayı o tarafta birakalım. 13 üncü kolordu, mütebaki aksamiyle ve ihtiyat süvarileriyle şimale gelip üçüncü orduya iltihak etsin. Diğer tekliflerinizi kabul ediyorum' dedi. 13 üncü kolordunun soğuk iklimde bir iş göremiyeceğini söyledimse de 'şimdi Ağustos, kışa kadar alışır' cevabını verdi.

\footnotetext{
${ }^{30}$ Paşa, Feryadım, s. 229-230.

${ }^{31}$ Pomiankowski, Osmanlı Imparatorluğunun, s. 12.

${ }^{32}$ Pomiankowski, Osmanlı Imparatorluğunun, s. 94.

${ }^{33}$ Pomiankowski, Osmanlı Imparatorluğunun, s. 97.

${ }^{34}$ Ali İhsan Sabis, Harp Hatıralarım Birinci Cihan Harbi, C.1, Nehir Yayınları, İstanbul 1990, s. 163-165.
} 
Fazla ısrar, daha sonra yapacağımız tekliflerin yolunu kapatabilirdi; şu halde onlart iyi giydirmek cihetine itina edilsin' dedim,"35

Bronsart Paşa gibi Goltz Paşa da Irak’taki mevcut askerî yapının bu bölgenin muhafazasına yeterli olabileceğini düşünmüştür. Goltz Paşa, Osmanlı Ordusu'nun savaşın ilk seyirlerindeki genel durumunu hatıralarında değerlendirirken konu ile ilgili: “ ...Kafkas hududunda ve Süveyş Kanalı karşısında toplanmakta olan Dördüncü Ordu'ya mensup kuvvetlerin toplanması hakkında alınan tertibat iyidir. Iran ve Irak kuvve-i seferiyyeleri hakkindaki tertibat da ziyansızdır" ${ }^{36}$ şeklinde bir tespitte bulunmuştur.

Bronsart ve Goltz Paşa'nın Irak coğrafyasında yer alan birlikleri yeterli addetmesinin ana nedeni Almanya'nın ilgili alanı kendi perspektifinden öncelikli savaş alanı olarak görmemesi ile açıklanabilir. Almanya esasen Kafkasya'da bulunan Ruslar ile Mısır'da yer alan İngilizlerin Osmanlı Ordusu tarafından tazyik altında tutulmasını beklediği için birliklerin ağırlıklı olarak bu alanlara kaydırılıp Irak'ın âtıl bir halde bırakılmasını pek önemsememiştir. Nitekim savaş sırasında Osmanlı Ordusu içerisinde görevli Alman subay von Kress'in anılarında bu mesele ile ilgili sarf ettiği şu cümleler oldukça değerlidir: “Alman Başkomutanlı̆̆ Genelkurmay Başkanı Orgeneral von Moltke'nin Enver'e gönderdiği, Türk müttefikinin yapacağ $\mathrm{l}$ vazifeler hakkındaki 10 Ăgustos 1914 tarihli yazısında, mümkün olduğu kadar çok Rus ve Ingiliz kuvvetinin bağlanması ve sıkı bir faaliyetle İslam ihtilalinin sağlanması açıkça istenmişti. Bu maksatların sağlanması için Kafkasya'ya karşı bir hareketle birlikte özellikle Mısır'a karşı bir teşebbüse girişilmesi arzu olunuyordu, 37

Osmanlı Ordusu'nda görevli bir diğer Alman subay Carl Mühlman da von Kress gibi kendileri açısından Doğu'da savaşın ana odak noktalarını Kafkasya ve Mısır olarak düşünmüştür. Onun anılarında dile getirdiği şu sözler bu konuya 1şık tutmaktadır: "Rusya ve Ingiltere'ye karşı girişilen harekâtlar Türkiye'nin katılımı sayesinde mümkün olmuştu. Bu harekâtların özelliği, etkileri bakımından onları ana muharebe cephelerinde alacakları taktik bir yenilgiden daha acıtıcı bir şekilde yaralayabiliyor olmalarındandı. Karadeniz kıyıları ve Kafkasya, Rusya'ya karşı uygun saldırı imkânları sunuyordu. Bundan daha az etkili olmayacak şekilde Ingiltere'ye karşı da Süveyş kanalı ve Mısır aynı saldırı imkânlarını sunmaktayd,, 38

Birinci Dünya Savaşı’nın ilk iki yılı içerisinde Alman Genelkurmay Başkanı olarak görev yapan Eric von Falkenhayn' in ${ }^{39}$ bu konu hakkındaki görüşleri genel anlamda Almanya'nın Osmanlı Devletinden savaşa yönelik beklentilerini yansıttığı için çok daha fazla önem atfetmektedir. Nitekim Falkenhayn, anılarında Türk birliklerinin özellikle Misır'da kullanımının ehemmiyetini şu sözler ile savunmuştur: "Yine bu sayede Mısır'a karşı Türk birlikleri sevk etmek imkânı da elde edilmişti. Genelkurmay başkanı bu hareketten hiçbir netice beklememekte ise de İngiltere'nin bellibaşlı stratejik bölgelerinden birisi olan Süveyş Kanalı'nı kesebilmek ve hiç olmazsa bu maksatla Alman kaynaklarının daha az kullanılmasina mukâbil, Ingiliz birliklerinden mühim bir klsmını harbin merkezinden uzak tutabilmiş olmayı ümit ediyordu, 40

\footnotetext{
${ }^{35}$ Sabis, Harp Hatıralarım, s. 176.

${ }^{36}$ Colmar Von Der Goltz, 20. Yüzyılın Başlarında Osmanlı-Alman İlişkileri “'Golç Paşa'nın Hâtıratı’, Çev., E. Kay. Salih Mayakuşu, Yay., Hz., Faruk Yılmaz, İz Yayıncılık, İstanbul 2012, s. 78.

${ }^{37}$ von Kress, Son Haçlı Seferi Kuma Gömülen Imparatorluk, Çev., Tahir Balaban, Yeditepe Yayınevi, İstanbul 2007, s. 17.

${ }^{38}$ Carl Mühlman, Imparatorluğun Sonu 1914, Çev. Kadir Kon, Timaş Yayınları, İstanbul 2009, s. 145.

${ }^{39}$ Eric von Falkenhayn, Birinci Dünya Savaşı'nda Almanya, Çev., Kurmay Yarbay Bursalı Mehmet Nihat, Yay., Hz., Faruk Yılmaz, İz Yayıncılık, İstanbul 2012, s. 27.

${ }^{40}$ Falkenhayn, Birinci Dünya, s. 59.
} 
Alman subayların Irak'a yönelik kayıtsızlığı Türk subaylarını olumsuz etkilemiştir. Irak’a yönelik hâkim Alman görüşü nedeniyle Türk subaylar bölgenin elden çıkmasının savaşın genel sonucuna hiçbir şekilde sirayet etmeyeceği fikrini benimsemişlerdir. Örneğin Hafız Hakk1 Paşa'nın bu konu ile alakalı şu görüşleri dikkat çekicidir: “Bugün Basra düştü. İki-üç haftadır fâik kuvvetlerle uğraşan bir avuç askerimiz en nihayet Basra'yı tahliyeye mecbur olarak Kurna'ya çekildi. Şimdilik Basra'nın sükutu asıl harp gayesine büyük tesir yapmaz. Meğer ki Araplık ihtilâline bir ocak olsun",41

Irak coğrafyasının âtıl bir vaziyette bırakılmasında Alman etkisi altında yer alan Osmanlı Genelkurmayının İran'a ve onun ötesine yönelik faaliyetler icra etme arzusu da önemli bir rol oynamıştır. Osmanlı-Alman ittifakının savaşa yönelik en önemli amaçlarından birisi Cihâd-1 Ekber'i İran'a ve onun ötesine yaymak olduğu için Osmanlı Genelkurmayında Irak yerine İran'a ordu birlikleri ve istihbarat elemanlarının gönderilmesi fikri daha fazla yoğunluk kazanmıştır. Nitekim bu kapsamda Karargâh-1 Umumide Enver Paşa ile Kazım Karabekir Paşa arasında geçen şu diyalog oldukça ilginçtir:

“Cemal Paşa Misır Seferini idare edecek, Hafiz Hakkı'yı da Erzurum'a gönderdim. Düşün bakayım, Tahran'a kimi göndereyim.

Ben-Paşam! Buyurduğunuz hareketi iyice kavrayamadım ki size, arzunuza muvafik kumandan bulayım! Iran hükümeti ile bir ittifak muahedesi yapıldı mı? Sonra, Ingilizlerin Bağdat üzerine yürüdükleri bir strada oraya ayrıca bir kuvvet tertip olundu mu? Bir de Üçüncü Ordu için bir taarruzî bir hareket mi düşünüldü? Ben bunlar hakkında hiçbir şey bilmiyorum.

Enver-Ben sana bu kararl verdim, buna bir kumandan bul diyorum. Sen bana bu hareketin tehlikesini söylemek istiyorsun. Iran, Rus nüfuzu altında bulundukça, bizimle siyasi bir taahhüde giremeyeceği meyandadır. Önce Tahran'l işgal ederiz, sonra orada ittifak muahedesini akdederiz. Băgdat'a gelince, Ingilizlerin hareketlerini buraya kadar uzatacakları henüz belli değil. İcap ederse bu kuvve-i seferiyemiz Iran'a girmeden evvel, Bağdat üzerine yürüyebilirler. Lüzum görmezse yoluna devam eder,"42

Osmanlı Genelkurmayının seferberliğin ilk zamanlarında asker sevkiyatının en zor olduğu bölgelerden birisi olan Irak'tan ordu birliklerini farklı nedenlerle çekmesi savaşın ilerleyen seyirlerinde kendisine negatif anlamda yansımıştır. Zira genelkurmay, Irak coğrafyasında Türk ve İngiliz kuvvetleri arasında muharebeler arttıkça bu alana yeni ordu birliklerini kaydırmak istemiştir. Fakat bölgeye yönelik ulaşım imkanlarının hali hazırda kısıtlı oluşu yeni ordu birliklerinin sevkiyatını zorlaştırmıştır. Nitekim Bahriye Nazırı ve 4'ncü Ordu Komutanı Cemal Paşa'nın 1914 Kasımının son günlerinde Suriye'ye varmaya çalışırken ulaşım imkanları ile alakalı tecrübe ettiği sıkıntıları betimlemek için sarf ettiği şu sözler oldukça düşündürücüdür:

“'Zorunlu olarak bir gece Beylan'da kalmak ve ertesi gün, klsmen at ile seyahat etmek suretiyle Katıma'ya (Katma) kadar yolumuza devam ettik. Katıma istasyonu, Bağdat şimendifer hattınin Halep'ten evvel ikinci istasyonudur. Halep-İskenderun şosesinin Bağdat hattına bă̆landiğı ilk nokta olduğundan', burada bir menzil noktası oluşturulmuştu. Fakat araba ile istasyonun elli metre mesafesine kadar gelmiş olduğumuz halde, istasyona kadar yolu takip etmek mümkün olamadı̆̆ını ve bu elli metrelik mesafeyi, gecenin zifiri karanlı̆̆ında neferlerin sırtında istasyona kadar

\footnotetext{
${ }^{41}$ Hafız Hakkı Paşa'nın Sarıkamış Günlüğ̈̈, Yay., Murat Bardakçı, Türkiye İş Bankası Kültür Yayınları, İstanbul 2016, s. 75.

${ }^{42}$ Kâzım Karabekir, I. Dünya Savaşı Anıları, Yay., Hz., Ziver Öktem, Yapı Kredi Yayınları, İstanbul 2018, s. 394.
} 
geçmek mecburiyetinde kaldığımızı söyleyecek olursam, vazifelilerin faaliyet ve himmet derecesini takdir edebilirsiniz.

$O$ anda, Balkan Seferi esnasındaki Kırkkilise (Kırklareli)-Edirne ve KırkkilisePinarhisar-Vize-Saray şosesi gözümün önüne geldi. O şoselerin de her iki tarafina böyle şerit gibi kırma taşlar yığllmış ve ortasına dolan yağmur sularından dolayı şose bir ark şeklini almıştı. Yarabbi! $O$ şose üzerinde yürüyemedikleri için tarlalara sapmaya mecbur olan bataryalarımızla, cephane ve askeri erzakımızın çamurlara saplanıp kaldığı o sefil ve heyecanlı manzaralar iki seneden beri hâlâ gözümün önünden gitmezken, şimdi benim kumandasına memur olduğum ordunun kapılarında da aynı hali görmek ne acı idi ${ }^{, 43}$

Savaş sırasında ordunun çeşitli kademelerinde görev almış askerlerin açıklamalarına ek olarak askerî tarih konusu ile alakalı çalışmalar gerçekleştiren uzmanların bu konu hakkında yaptığ $\breve{1}_{1}$ değerlendirmeler de dikkate değer niteliktedir. Örneğin ağırlıklı olarak son dönem askerî tarihi hakkında yaptığı çalışmalar ile tanınan Edward Erickson Osmanlı Genelkurmayının Irak'a yönelik stratejik hatasını bir çelişki ekseninde izah etmeye çalışmaktadır:

"Belki de Türklerin savaşın ilk günlerinde yaptıkları en önlenebilir ve ciddi hata, Mezopotamya'da yeterli savunma güçleri bulundurmamaktı. Şattülarap'ın korunmasız bırakılması kapıyı Mezopotamya'daki Ingiliz güçlerine açtı ve onlar da bütün savaş boyunca burada kaldılar. Ingilizler sonunda bölgeye Türklerin burada bulundurduklarının iki katı asker gönderdiler. Bu, imparatorluk için birbiriyle çekişen farklı stratejik öncelikler yaratan ve savaşın sonuna kadar süren tehlikeli bir durumdu, 44

2. Kut Kuşatması Sonrasında 13'ncü Kolordu'nun İran İçerisine Gönderilmesi ve Bu Durumun 6'ncı Ordu'nun Bağdat Savunmasına Etkisi

Osmanlı Genelkurmayının savaşın ilk seyirlerinde Irak'a yönelik hatalı inisiyatifleri İngiliz kuvvetlerinin ilgili coğrafyaya yerleşmesine olanak sağlamıştır. Fakat 1915 yılının yaz aylarından itibaren sahadaki İngiliz kuvvetlerinin Londra ve Delhi hükümetlerinin yaşadıkları anlaşmazlıklar neticesinde lojistik, insan kaynağı, iklim vb. faktörleri dikkate almaksızın Basra istikametinden Bağdat'a doğru hareket etmeleri, bu duruma paralel olarak Türk kuvvetlerinin bu süreçte alanda bulunan 35 'nci ve 38 'nci tümenlere ek olarak yeni oluşturulan 45 'nci Piyade Tümeni ile Doğu Cephesi'nden gelen takviye 51'nci ve 52'nci Piyade tümenlerin sayesinde kuvvetlenmesiyle güç dengesi tam tersine dönmüştür. Bunun sonucunda İngiliz kuvvetleri 1915 yılının aralık ayı içerisinde Bağdat'a ulaşamadan Selman-1 Pak adı verilen noktada durdurulmuş akabinde Kut adı verilen noktada kuşatılmıştır. Böylece Irak’ta Türkler ile İngilizler arasında Kasım 1914 tarihinden itibaren devam eden mücadele de farklı bir eksene doğru kaymaya başlamıştır ${ }^{45}$.

General Townshend'in komutası altında yer alan İngiliz kuvvetlerinin Kut'ta kuşatıldığı sırada Goltz Paşa, Osmanlı Genelkurmayının emri ile Irak'ta yer alan birliklerin komutasını üstlenmek amacıyla bölgeye hareket etmiştir. Nitekim kendisi, aralık ayı içerisinde Irak'a ulaşarak birliklerin komutasını üstlenmeye başlamıştır. Fakat aynı süreçte kuşatma altında yer

\footnotetext{
${ }^{43}$ Cemal Paşa, Hatıralar, Yay., Hz., Alpay Kabacalı, Türkiye İş Bankası Kültür Yayınları, İstanbul 2016, s. 171.

${ }^{44}$ Erickson, Size Ölmeyi Emrediyorum!, s. 76-77.

${ }^{45}$ Bolvadinli Mehmet Sinan Bey'in Harp Hatıralarl, Mehmet Sinan Bey, Yay., Hz., Servet Yaşar, Hasan Babacan, Muharrem Bayar, Türkiye İş Bankası Kültür Yayınları, İstanbul 2011, s. 43-vd; Erickson, Size Ölmeyi Emrediyorum!, s. 152-157; Pomiankowski, Osmanlı Imparatorluğunun, s. 87.
} 
alan İngiliz birliklerini rahatlatmak maksadiyla General Baratov öncülüğündeki Rus kuvvetlerinin İran'dan Bağdat istikametine doğru hareket etmeleri Türk-Alman ittifakının yönünü İran'a çevirmesine neden olmuştur ${ }^{46}$.

Esasında İran, Türk-Alman itifakının savaşın başından itibaren etkili olmaya çalıştığı, üzerine birtakım stratejiler ve faaliyetler tatbik etmeye çalıştığı bir ülke olarak ön plana çıkmıştır. Türk-Alman ittifakının İran'daki temel maksadı, Cihâd-1 Ekber'i bu ülke üzerinden Afganistan, Pakistan ve Hindistan'a taşıyarak İngiltere'yi sömürgelerinde hapsetmek olarak tasarlanmıştır. Nitekim bu kapsamda Osmanlı Genelkurmayı bir taraftan 1914 yılının Eylül ayından itibaren Ömer Naci, Ruşeni Bey, Rauf Bey gibi önemli Teşkilat-1 Mahsusa üyelerini bu alana göndererek diğer taraftan da Tahran'da bulunan sefiri Asım Bey aracılığılla kendisini İran'da konumlandırmaya çalışmıştır. Türk tarafının bu teşebbüsüne Almanlar ise İran'da bulunan konsolosluk çalışanları ve istihbarat elemanlarının faaliyetleri vasıtası ile karşılık vermiştir. Fakat bilhassa 1915 yılının bahar aylarından itibaren Türkler ile Almanlar arasında İran konusunda derin fikir ayrılıklarının oluşması ittifakın sahadaki etkinliğini yavaş yavaş ortadan kaldırmıştır. Bunun sonucunda Almanların İran'da Türklerden bağımsız bir şekilde hareket ederek dengeleri tamamen kendi lehlerine çevirme girişimlerine hali hazırda İran'da etkin bir askerî güce sahip Rusya kayıtsız kalmamış ve başta Tahran olmak üzere İran'ın önemli bir kısmını 1915 yılının sonuna kadar işgal etmiş̧ir. Böylece İran'daki Türk-Alman ittifakı da büyük bir yara almıştır ${ }^{47}$.

Goltz Paşa'nın geniş yetkiler ile Irak'a tayin edilmesi ise hali hazırda İran'a yönelik sürüncemede kalan Türk-Alman ittifakının yeniden gündeme gelmesini sağlamıştır. Bu kapsamda Goltz, aralık ayı içerisinde Irak'a geldikten sonra ilk etapta Kirmanşah'a doğru ilerleyen General Baratov komutası altındaki Rus kuvvetlerini durdurabilmek için Şevket Bey’in emri altında üç taburluk bir Türk birliğini Batı İran'a sevk etmiştir. Arkasından da bir Alman subayın komutası altında yer alan başka bir Türk taburunu ilgili alana göndermiştir. Fakat Batı İran'daki durumun kötüleşmesi üzerine Bağdat'ta daha fazla bekleyemeyerek Kirmanşah'a hareket etmiştir. Nitekim 1 Ocak günü Kirmanşah'a vararak vaziyeti bizatihi yerinde görmüştür. Kirmanşah'daki durumun Rusların lehine gelişme ihtimalinin artması üzerine çok fazla itimat ettiği Albay Bob'u İran Cephe Komutanı olarak tayin ederek yeniden Bağdat'a dönmüştür ${ }^{48}$.

Albay Bob'un İran'da yer alan kuvvetlerin komutanı olarak tayin edilmesi Batı İran'daki durumun Türk-Alman ittifakının aleyhine gelişmesini engelleyememiştir. Hatta ocak ayı içerisinde şiddetlenen çatışmalar nedeniyle Albay Bob, Goltz'a bir ara görevi bırakmak

\footnotetext{
${ }^{46}$ Sean McMeekin, I. Dünya Savaşı'nda Rusya'nın Rolü, Çev., Nurettin Elhüseyni, Yapı Kredi Yayınları, İstanbul 2013, s. 226; Goltz, Osmanll-Alman İlişkileri, s. 127-135; Pomiankowski, Osmanlı İmparatorluğunun, s. 143-144.

${ }^{47}$ Ramazan Sonat, “Tahran Sefiri Asım Bey'in Raporları Doğrultusunda Birinci Dünya Savaşı Sırasında İran'daki Rus Askerî Varlığı Üzerine Bir İnceleme”, Osmanlı Mirası Araştırmaları Dergisi, C. 5, S. 18, (Kasım 2018), s. 179191; Mansoureh Ettehadiyyeh, “İran Geçici Hükümeti”, İran ve I. Dünya Savaşı Büyük Güçlerin Savaş Alanı, Edit., Touraj Atabaki, Çev., Gül Çağalı Güven, Tarih Vakfı Yurt Yayınları, İstanbul 2010, s. 10-12; Touraj Atabaki, “'Doğu'ya Yöneliş: İran'da Osmanlı İstihbarat Servisinin Faaliyetleri', İran ve I. Dünya Savaşı Büyük Güçlerin Savaş Alanı, Edit., Touraj Atabaki, Çev., Gül Çağalı Güven, Tarih Vakfı Yurt Yayınları, İstanbul 2010, s. 29-37; Sadık Sarısaman, "Ömer Naci Bey Müfrezesi”, Ankara Üniversitesi Türk Inkılâp Tarihi Enstitüsü Dergisi Atatürk Yolu, S. 16, (1997), s. 501-513; Rıdvan Ayaydın, Birinci Dünya Savaşı'nda Osmanlı Devleti'nin Iran'da Cihad-ı Ekber Faaliyetleri, İstanbul Üniversitesi Sosyal Bilimler Enstitüsü Basılmamış Doktora Tezi, İstanbul 2016; Çağdaş Yüksel, Birinci Dünya Savaşı Yıllarında Teşkilat-ı Mahsusa, Pamukkale Üniversitesi Sosyal Bilimler Enstitüsü Basılmamış Doktora Tezi, Denizli 2019, s. 92-120; Sadık Sarısaman, "Birinci Dünya Savaşı Sırasında İran Elçiliğimiz İle İrtibatlı Bazı Teşkilat-1 Mahsusa Faaliyetleri”, OTAM, 7, (1996), s. 209-217; Koloğlu, Curnalcilikten, s. 109-113; Goltz, Osmanl-Alman İlişkileri, s. 117-120; Falkenhayn, Birinci Dünya, s. 59.

${ }^{48}$ Pomiankowski, Osmanlı Imparatorluğunun, s. 145; Goltz, Osmanlı-Alman İlişkileri, s. 141-143; McMeekin, I. Dünya Savaşı'nda, s. 226.
} 
istediğini iletmiştir. Bu arada Türk kuvvetleri ve İran'da yer alan yerel kuvvetlerin fazla mukavemet gösterememesi nedeniyle Baratov önderliğindeki Rus ilerleyişi hız kazanmıştır. Nitekim şubat ayına gelindiğinde Batı İran'daki durumun ciddi anlamda kötüleşmesi üzerine Goltz Paşa bu alana yönelik birtakım yeni inisiyatifler alma kararı almıştır ${ }^{49}$.

Goltz Paşa'nın bu süreçte aldığı en radikal hüküm Enver Paşa'nın Ocak 1916 tarihinde orduya yönelik gerçekleştirdiği yeni düzenlemesi çerçevesinde takviye güç olarak Bağdat'a gönderilmesine karar verilen 2'nci ve 6'ncı tümenlerden 2'nci Tümeni Batı İran'a sevk etmek olmuştur. Fakat onun bu girişimi de pek bir fayda getirmemiş ve şubat ayının sonlarında Rus kuvvetleri Kirmanşah'1 işgal etmiştir ${ }^{50}$.

Goltz Paşa'nın bütün bu çabalarına karşılık mart ve nisan ayları Türk ve Rus kuvvetlerinin Batı İran'daki konumlarını sağlamlaştırması ile geçmiştir. Aynı süreçte Goltz Paşa, Halil Paşa ile birlikte Kut'ta kuşatılan İngiliz birliklerine karşı kesin bir netice alabilmek için ciddi anlamda çaba sarf etmiştir. Fakat onun nisan ayının ortalarına doğru hastalanıp hayatını kaybetmesi ile İran'a yönelik Türk-Alman ittifakının geleceği tartışmalı bir hal almaya başlamıştır ${ }^{51}$.

Nisan ayının sonlarında kuşatma altında yer alan İngiliz kuvvetlerinin esir alınması Batı İran'da yer alan Baratov önderliğindeki Rus kuvvetlerinin Bağdat yönüne doğru hareketlenmelerine sebebiyet vermiştir. Bu kapsamda Rus kuvvetleri 3 Mayıs günü Paytak Boğazı'nı ele geçirerek Türk birliklerinin İran-Irak sınırının kesişme noktasında yer alan Hanekin'e çekilmesini sağlamıştır. Bu gelişme üzerine İran'da yer alan Alman ve Türk subayların Bağdat'a gitmeleri ile ülkeye yönelik Türk-Alman ittifakı çökme noktasına gelmiştir. Fakat Enver Paşa'nın içerisinde Alman subayların da yer aldığı maiyeti ile birlikte mayıs ayının ilk haftası Bağdat'a gelmesi İran'a yönelik Türk-Alman ittifakının yeniden önem kazanmasını sağlamıştır. Nitekim Enver Paşa Bağdat'a gelir gelmez burada bulunan 6'ncı Ordu'yu iki kısma ayırmış, 45'nci, 51'nci ve 52'nci tümenleri 18 'nci Kolordu çatısı altında birleştirmiş buna mukabil 2'nci, 4'ncü ve 6'ncı tümenleri ise Ali İhsan Paşa'nın komuta edeceği 13 'ncü Kolordu çatısı altında birleştirerek İran'a sevk etme kararı almıştır. Böylece İran'a yönelik Türk-Alman ittifakı yeniden işlevlik kazanmışıı ${ }^{52}$.

Rusların üzerine sevk edilen 13'ncü Kolordu mayıs ayından itibaren başarılı operasyonlar gerçekleştirerek İran içerisinde ciddi bir mevki elde etmiştir. Hatta haziran ayında Kirmanşah'1 Rusların elinden almayı başararak ilk ciddi başarısını kazanmıştır. Temmuz ayına gelindiğinde ise bir başka önemli şehir olan Hemedan'1 ele geçiren 13'ncü Kolordu bu arada kendisini Bağdat'tan yaklaşık dört yüz kilometre uzakta bulmuştur ${ }^{53}$.

13'ncü Kolordu'nun İran'da aktif bir pozisyon aldığı süreçte Irak'ta yer alan İngiliz kuvvetleri General Maude komutanlığ 1 altında kendilerini yeniden reforme ederek Bağdat istikametine doğru yürüyüşe geçmek için emir beklemeye başlamışlardır. Fakat Maude, hazırlıklar tamamlanmadan yapılacak bir harekatın kesin bir netice vermeyeceğini düşündüğü için uzun bir süre birliklerini yerinden kımıldatmayarak en doğru zamanı beklemiştir. Nitekim

\footnotetext{
${ }^{49}$ Goltz, Osmanlı-Alman İlişkileri, s. 147-151; McMeekin, I. Dünya Savaşı'nda, s. 228; Pomiankowski, Osmanlı Imparatorluğunun, s. 145.

${ }^{50} \mathrm{Goltz}$, Osmanll-Alman İlişkileri, s. 151; Pomiankowski, Osmanlı İmparatorluğunun, s. 178.

${ }^{51}$ Liman von Sanders, Türkiye'de Beş Sene, Çev., Osmanlı Genelkurmayı Askeri Tarih Encümeni Tercüme Heyeti, Yay., Haz., Muzaffer Albayrak, Yeditepe Yayınları, İstanbul 2013, s. 163-164; Pomiankowski, Osmanl İmparatorluğunun, s. 183; Goltz, Osmanlı-Alman İlişkileri, s. 168-172.

${ }^{52}$ Pomiankowski, Osmanlı Imparatorluğunun, s. 183-184; Bolvadinli Mehmet Sinan Bey'in, s. 75-76; Erickson, Size Ölmeyi Emrediyorum!, s. 215-216.

${ }^{53}$ Bolvadinli Mehmet Sinan Bey'in, s. 77-83; Pomiankowski, Osmanlı Imparatorluğunun, s. 185; Erickson, Size Ölmeyi Emrediyorum!, s. 216.
} 
hem birliklerin hazırlıklarının tamamen bitmesi hem de iklimin elverişli olmasından ötürü Aralık 1916 tarihinde birliklerini Dicle Nehri üzerinden Bağdat'a doğru harekete geçirebilmiştir ${ }^{54}$.

İngiliz kuvvetlerinin ilerleyiși karşısında bu sefer Bağdat'ta yer alan 6'ncı Ordu Karargahında bir panik havası oluşmaya başlamıştır. Bu panik havasını ortadan kaldırabilmek için Halil Paşa ilk iş olarak elinde bulunan kuvvetlerin yetersizliğini de düşünerek İran'da bulunan Ali İhsan Paşa'yı emri altındaki 13'ncü Kolordu ile birlikte Bağdat'a çağırmıştır. Fakat ondan ilk etapta olumlu bir cevap alamamıştır. Bunun üzerine konunun önemini tekrardan Ali İhsan Paşa'ya anımsatarak 13'ncü Kolordu'nun Şubat 1917 tarihinde İran'dan Bağdat istikametine doğru hareket etmesini sağlamıştır ${ }^{55}$.

Halil Paşa'nın çabaları ile 13'ncü Kolordu İran'dan hareket ettiği sırada İngiliz kuvvetleri ilerleyişlerini hızlandırmışlardır. Halil Paşa da Dicle Nehri üzerinde harekete geçen İngiliz kuvvetlerine karşı elinde bulunan kuvvetleri yüz kilometrelik geniş bir alana yayarak beklemeye başlamıştır. Fakat o, Maude önderliğindeki İngiliz birliklerinin nicelik ve niteliksel açıdan üstünlüğü ve kendi birliklerinin lojistik sisteminin işlevselliği ${ }^{56}$ karşısında daha fazla dayanamayarak kuvvetlerini yerlerinden oynatmak zorunda kalmıştır. Şubat 1917 tarihi itibariyle hız kazanan İngiliz ilerleyişi de mart ayının ortalarına doğru Bağdat'ın ele geçirilmesi ile nihayete ermiştir. 13'ncü Kolordu ise Bağdat ele geçirildiği sırada kendisini ancak yeni yeni Irak sınırlarına atabilmiştir ${ }^{57}$.

Osmanlı Genelkurmayının Irak'ta İngilizler ile yoğun bir muharebe yaşanırken 13'ncü Kolordu'yu İran'a göndermesi ve 6'ncı Ordu'nun gücünü zafiyete uğratması oldukça tartışmalı bir karardır. En başta 13'ncü Kolordu'nun İran'a gönderilmesinde Türk tarafının mı yoksa Alman tarafinın mı daha fazla etkisinin olduğu belirsiz bir konudur. Zira 13'ncü Kolordu'yu İran'a gönderen iradenin hali hazırda Irak'ta güçsüz bir şekilde vücut bulmuş askerî yapıyı hangi sebepler ile zafiyete uğratmayı göze aldığı meselesi oldukça karışıtır. Bu girişim Almanların Cihâd-1 Ekber'i İran'a ve onun ötesine yayma fikrine mi hizmet etmekteydi veyahut Türk tarafının Turan rüyasının bir neticesini mi yansıtmaktaydı. Bu konu kapsamında Türk ve Alman subayların anılarında geçen ifadeler tarafların birbirlerini suçlaması șeklinde tezahür etmektedir. Örneğin Liman von Sanders anılarında 13'ncü Kolordu'nun İran'a gönderilmesini Goltz Paşa'nın ölümünden sonra ortaya çıkan güç boşluğunun bir yansıması olarak değerlendirmiş ve Halil Paşa ile Ali İhsan Paşa'yı bu düşüncesiz girişimin baş sorumluları olarak tanımlamıştır. Liman Paşa'nın anılarında bu konu ile ilgili sarf ettiği şu sözler Türk ve Alman subaylar arasında yaşanan güç savaşını çok güzel bir şekilde özetmektedir:

“'Irak'ta 6. Ordu'da açık bir sevk ve idare yok gibi görünüyor. Halil Paşa ordu komutanindan başka her şeydir; Kutülamare muzafferiyetinden sonra Ingilizlere Felâhiye'de taarruz ederek Irak'ın hiç olmazsa bir kısmını tahliyeye mecbur edecek yerde, çok nüfuzlu ve akıll fakat entrikacı ve Almanlara dost olmayan İhsan Paşa'yl

\footnotetext{
${ }^{54}$ British Army, "Operational Lessons", s. 342; Ulrichsen, "The British Occupation”, s. 359-vd; Erickson, Size Ölmeyi Emrediyorum!, s. 226-227.

${ }^{55}$ Bolvadinli Mehmet Sinan Bey'in, s. 88-89.

${ }^{56}$ Bilhassa Kut kuşatması sonrasında güçlendirilmesi gereken lojistik sistem güçlendirilmemiş ve ordu ikmal sisteminin zafiyete uğramasına neden olmuştur. Bu konuda yapılmış bir çalışma için bkz: Serdar Sakin, "Ordu Lojistik Sisteminin Önemi Açısından Kut'ül-Amare Savaşı ve Resulayn-Musul Menzil Hattı”, SBArD, (Eylül 2009), s. $13-25$.

${ }^{57}$ Erickson, Size Ölmeyi Emrediyorum!, s. 227-228; Ulrichsen, “The British Occupation", s. 360; Bolvadinli Mehmet Sinan Bey'in, s. 91-94.
} 
Hanikin üzerinden Kirmanşah'a gönderiyor ve Rusların birkaç taburla (2-3), birkaç süvari alayına (5 kadar) karşı, Türk basını tarafindan göklere çıkarılan kolay bir takım başarılar kazanmak peşine düşüyor.

İan'a karşı yapılan bütün bu harekât boşluğa kılıç sallamak gibidir. Çünkü birincisi oradaki başarı devamsızdır; ikincisi halkı askerliğe alışmamış ve güvenilmez olan İan üzerine yapılması tasarlanan baskının, Dünya Savaşı'nın sonucu üzerine hiçbir tesiri yoktur, 58

Liman Paşa her ne kadar 13'ncü Kolordu'nun İran'a gönderilmesini Halil Paşa ve Ali İhsan Paşa'nın düşüncesiz girişimi olarak ifade etse de bu kolordunun içerisinde yer alan Alman personelin varlığını tam anlamıyla izah edememiştir. Ayrıca o, Irak’ta İngilizler ile yoğun bir muharebe yaşandığı sirada 13'ncü Kolordu'nun hangi maksatlarla İran'a gönderildiği konusunda da net bir fikir üretememiştir. Fakat Avusturya-Macaristan İmparatorluğu'nun savaş sırasında İstanbul'daki büyükelçiliğinde askeri ataşe olarak görev yapan General J. Pomiankowski anılarında bu girişimin temel sebebini Enver Paşa'nın Panturanizm planının yansıması olarak açıklamıştır. Pomiankowski, planın hazırlanışını ve Almanların bu planın neresinde olduğunu anılarında şu sözler ile değerlendirmiştir: "Planın hazırlanışında herhalde Enver ve Halil'in yanında Orsova'da General Falkenhayn ile Enver Paşa'nın görüşmelerinin payl ve ayrıca General Lossow'un da etkisi bulunduğu santliyordu. Alman personel ve birliklerinin Irandaki ileri harekâta büyük ölçüde katılmış oldukları da ayrıca dikkat çekicidir. Bunlar, istihkâm subaylarının büyük bir kısmı ve özel bir istihkâm komandosu ile iki Alman seyyar hastanesi ve birde Alman kamyon konvoyunu oluşturuyordu, 59

13'ncü Kolordu'nun İran içerisine Panturanizm ideolojisi sebebi ile sevk edildiğini iddia eden bir diğer isim Ahmet İzzet Paşa olmuştur. Anılarında bu işin en büyük müsebbibini Enver Paşa olarak gösteren Ahmet İzzet Paşa meseleyi daha da ileri götürerek Ali İhsan Paşa'nın bile 13'ncü Kolordu'nun tamamının İran'a sevk edilmesi konusunda muhalif bir tutum takındığını şu sözler ile iddia etmiştir:

“'Şu durumlara göre, 6. Ordu'ca kabul edilecek genel plan neden ibaret olmallydl? En tabii olarak hatıra gelen tedbir, Kutü'l-Amare kuşatmasından serbest kalanları da Felâhiye'deki kuvvetlerimize katmak ve Kutü'l-Amare Zaferi'yle heyecana kapılan ahaliden büyücek bir kuvvet teşkil ederek Ingilizlerin Felâhiye güneyindeki asıl kuvvetlerini dört taraftan sikıştırıp tehdit ederek geri çekilmeye ve Irak'ı boşaltmaya zorlamak ve kuşatma ile General Townshend'in âkıbetine uğratmaktı.

Felâhiye'deki askerimizi mağlup edemeyen bir düşmanın, bu asker takviye edilip arttırllırsa karşısında mağlup olması çok muhtemeldir. Fakat bu esnada cepheye gelmekle şeref veren genel karargâh, yine fütuhat hastalığına tutularak taban tabana zit bir karar aldı. Bütün 13. Kolordu'yu, kumandanı Ali İhsan Paşa'nın da görüşüne aykırı olarak Iran'a saldırttı.

Ayrıntılarına gerek görmediğim bu İran seferine dair işittiğim bir konferansa göre, Ihsan Paşa bu seferde harekâtı gerçekten güzel bir şekilde yönetmiş ve pek çok askerî meziyetler göstermistir. Fakat bu kolorduyla muktedir kumandanının buradaki her bir galebesi, genel karargâhın hesabına yazılacak stratejik bir hatadır. Çünkü 6. Ordu'yu

\footnotetext{
${ }^{58}$ Sanders, Türkiye'de, s. 164-165.

${ }^{59}$ Pomiankowski, Osmanlı Imparatorluğunun, s. 185.
} 
böyle maddi ve fikri kuvvetten mahrum etmekle, ikinci defa olarak Irak facialarına sebep olmuştur,, 60

13'üncü Kolordu'nun İran'a gönderilmesini Panturanizm ideolojisi ile bağdaştıran bir başka üst düzey isim Cemal Paşa olmuştur. Cemal Paşa'nın bütün muharebe alanlarına yönelik gerçekleştirdiği değerlendirmelere ek olarak bu konu ile ilgili anılarında sarf ettiği şu cümleler hem yapılan stratejik hatayı hem de ideolojik amacı göstermesi bakımından oldukça dikkat çekicidir: "'Küt-ül Ammare'deki Ingiliz ordusunun esir düşmesinden sonra, Irak ordusunun bir kısmının alınarak Iran'da fetihlerle görevlendirilmesi, sonunda Bağdat'ın düşmesine sebep olmuştu, 61

Olayların başrolünde yer alan Ali İhsan Paşa kaleme aldığı anılarında en çok Liman von Sanders ve Falkenhayn gibi Alman subayların birçok muharebe alanında birliklerin savaşma kabiliyetini olumsuz etkilediklerini ve onların Türk subaylarını pasif hale getirmeye çalıştıklarını eleştiriye tâbi tutmuştur. Ayrıca Ali İhsan Paşa anılarında sık sık Alman subayların yanı sıra Enver Paşa ile 6'ncı Ordu Komutanı Halil Paşa'yı düşüncesiz hareket etmek ile suçlamıştır. Kendisinin komuta ettiği 13'ncü Kolordu'nun İran'a gönderilmesini ise istenmeyerek yapılan bir aksiyon olarak tanımlamışıı ${ }^{62}$.

Ali İhsan Paşa'nın yanı sıra Kazım Karabekir Paşa'da anılarında Almanların İran'a yönelik arzu ve emellerinin bu ülkeye yönelik bir harekâtı zorunlu kıldığını ifade etmiştir. Kazım Karabekir Paşa'nın henüz 13'ncü Kolordu İran'a sevk edilmeden önce Goltz Paşa ile gerçekleştirdiği görüşmenin akabinde dile getirdiği şu cümleler kayda değer niteliktedir: “Zavallı İran'in vaziyeti hakkında mütalaa serdine lüzûm kalmıyor. Fena olan cihet şu ki Almanlar da kendi hesaplarına çalıştıklarından ileride Irak cephesini zarara sokacak münasebetsizlikleri Türk kanıyla durdurmaya çalışacağımıza şüphe etmiyordum. Almanların bütün aşiretleri Iran'a fazla düşman kuvvetleri celb etmektir. Bu suretle Alman ordusuna yardım ettikleri gibi şimdiden taraftar ve nüfuz kazanarak harp sonunda Iran'da bazı siyasi kazançlar teminine çalışıyorlar ",63

\section{Tartışma ve Sonuç}

Ağırlıklı olarak Alman etkisi altında bulunan Osmanlı Genelkurmayının Birinci Dünya Savaşı sırasında harp alanlarına yönelik inisiyatifleri özelde Bağdat'nn genelde Irak coğrafyasının tamamının elden çıkışına neden olan en önemli etken olmuştur. En başta Almanların doğuda savaşı ekseriyetle Kafkasya ve Mısır'a yayma istekleri buna bağlı olarak Osmanlı Genelkurmayını ordu birliklerini çoğunlukla bu alanlara yönlendirmeye zorlamaları Irak coğrafyasının âtıl bir vaziyette kalmasına neden olmuş ve bu durumdan istifade eden İngilizlerin bölgede yerleşik bir vaziyet almalarına sebebiyet vermiştir. Nitekim Osmanlı Genelkurmayının kendilerine sağladığı boşluktan yararlanan İngilizler kısa sürede bölgede yerleşik pozisyondan taarruz konumuna geçerek Irak coğrafyasında daha fazla mevki elde etmeye başlamışlardır. İngilizler mevki kazandıkça da Bağdat'ı ele geçirmenin kendileri açısından zor bir olay olmayacağını düşünerek bu noktaya doğru ilerleyişlerini sürdürmüşlerdir. Fakat İngiliz birliklerinin sahada karşılaştıkları bazı problemler ve Osmanlı Genelkurmayının seferberliğin ilk zamanlarında yaptığı hatadan vazgeçip Irak'a ek birlik sevkiyatı

\footnotetext{
${ }^{60}$ Paşa, Feryadım, s. 233-234.

${ }^{61}$ Paşa, Hatıralar, s. 215.

${ }^{62}$ Sabis, Harp Hatıralarım, C. 1, s. 76-vd, 194-195; Ali İhsan Sabis, Harp Hatıralarmm Birinci Cihan Harbi, C. 4, Nehir Yayınları, İstanbul 1991, s. 15, 22-24.

${ }^{63}$ Karabekir, I. Dünya, s. 508.
} 
gerçekleştirmesi ile Bağdat'a yönelik bu ilk teşebbüs Kut duvarına çarparak başarısızlıkla neticelenmiştir.

Her ne kadar İngilizler Bağdat'ı ele geçirme noktasında ilk etapta başarısız olsalar da Irak'ta yerleşik bir pozisyona sahip olmalarının avantajlarını kullanarak kısa süre sonra tekrar bu girișimlerini tatbik etmek istemișlerdir. Nitekim Kut kuşatması sonrasında Türk-Alman ittifakının ortak bir projesi şeklinde 13'ncü Kolordu'nun İran'a gönderilmesi ve Irak'ta yalnız savunmaya 18'nci Kolordu'nun bırakılması İngiliz birliklerinin sahada lojistik, insan kaynağ vb. enstrümanlarla desteklenmesi ile birleşince bu amacın gerçekleşmesi için ortada hiçbir gerekçe kalmamıştır. Netice itibariyle Ortadoğu'nun en önemli üs merkezlerinden birisi olan Bağdat'ın İngilizler tarafından ele geçirilmesi hem onlar adına Irak'ın kontrol altına alınmasını sağlamış hem de ilerleyen süreçlerde bir anlamda Anadolu coğrafyasına gerçekleştirilecekleri olası bir harekâtın yapıtaşını oluşturmuştur.

Bağdat'ın hem Anadolu hem de Arabistan coğrafyasının kesişiminde yer alması, Ortadoğu'nun en önemli üs merkezlerinden birisi olması ve ona sahip olana vadettiği avantajlar bu kadar belirginken Osmanlı Genelkurmayının Birinci Dünya Savaşı sırasında onu bir değil iki defa savunmasız bırakması nasıl açılanabilir? Kanaatimize göre Osmanlı Genelkurmayı belirlediği öncelikli -Kafkas ve Mısır- savaş alanlarında Almanların desteği ile elde edeceği başarılara çok fazla güvendiği için özelde Bağdat'ın genelde Irak coğrafyasının elden çıkabileceği ihtimalini hiçbir zaman öngörememiştir. Bu sebepten hem savaşın başında hem de Kut kuşatmasının ardından Irak'a ayrılan kuvvetleri farklı harp alanlarına sevk etme konusunda hiçbir beis görmemiştir. Ayrıca bu teşebbüsün arkasında güçlü bir Alman desteğinin olması Osmanlı Genelkurmayının aldığı kararı iç muhasebe edebilmesine olanak sağlamamıştır. Bunlara ek olarak Enver Paşa'nın tek adam yönetimi ve yalnızca Türk subaylar ile değil Alman subaylar ile görüş alışverişinden olabildiğince kaçınması da yabana atılmayacak bir gerekçe olarak ortada durmaktadır.

Bu olumsuzluklar göz ardı edildiğinde yine de Osmanlı Devleti savaş sırasında Bağdat'1 elinde tutabilir miydi? Kanaatimize göre bu sorunun cevabını verebilmek bir hayli güçtür. Fakat bilhassa savaşın başlangıcında Irak'ta yer alan 12'nci ve 13'ncü Kolordu'yu yerlerinde tutup onların birtakım ek kuvvetlerle desteklenmesi durumunda İngilizlerin bölgede yerleşik bir pozisyon almaları geciktirilebilirdi. Bu durumda Osman Genelkurmayına zaman kazandıracağı için Irak'ta daha güçlü bir savunma anlayışının benimsenmesine bir anlamda olanak sağlayabilirdi. Ayrıca Osmanlı Genelkurmayının 13'ncü Kolordu'yu İran'a göndermek yerine müttefiklerini desteklemek maksadıyla Avrupa'ya gönderdiği birlikleri Irak veyahut diğer zayıf savaş noktalarında kullanabilmesi de onun harp kabiliyetine pozitif açıdan katkı sağlayabilecek etkenlerden birisi olarak ortaya çıkabilirdi. 


\section{Kaynakça}

The National Archives

Foreign Office (FO) 416/111

\section{Kaynak Eserler}

Ahmet İzzet Paşa, Feryadım, İstiklâl Harbi'nin Gerçekleri, Yay. Haz., Süheyl İzzet Furgaç-Yüksel Kanar, C. 1, Timaş Yayınları, İstanbul 2017.

AKSAKAL, Mustafa; Harb-i Umumi Eşiğinde Osmanlı Devleti Son Savaşına Nasıl Girdi?, İstanbul Bilgi Üniversitesi Yayınları, İstanbul 2010.

AKTAŞ, Hayati; “Birinci Dünya Savaşı'nda Türkiye'de Görev Yapan Alman Subaylarının Faaliyetlerinin Bir Değerlendirmesi ve Türk Askerinin Konumu', History Studies International Journal of History, Vol., 11, Issue., 2, (April 2019), s. 469-482.

ATABAKI, Touraj; 'Doğu’ya Yöneliş: İran'da Osmanlı İstihbarat Servisinin Faaliyetleri'”, İan ve I. Dünya Savaşı Büyük Güçlerin Savaş Alanı, Edit., Touraj Atabaki, Çev., Gül Çağalı Güven, Tarih Vakfı Yurt Yayınları, İstanbul 2010, s. 29-43.

AYAYDIN, Rıdvan; Birinci Dünya Savaşı'nda Osmanlı Devleti'nin Iran'da Cihad-ı Ekber Faaliyetleri, İstanbul Üniversitesi Sosyal Bilimler Enstitüsü Basılmamış Doktora Tezi, İstanbul 2016.

Bolvadinli Mehmet Sinan Bey'in Harp Hatıraları, Mehmet Sinan Bey, Yay., Hz., Servet Yaşar, Hasan Babacan, Muharrem Bayar, Türkiye İş Bankası Kültür Yayınları, İstanbul 2011.

BOZTEMUR, Recep; “Arap İsyan1, 1916-1918”, Mülkiye, C. XXXV, S. 272, (2011), s. 6179.

Cemal Paşa, Hatıralar, Yay., Hz., Alpay Kabacalı, Türkiye İş Bankası Kültür Yayınları, İstanbul 2016.

Çİ̧EK, M. Talha; "Erken Cumhuriyet Dönemi Ders Kitapları Çerçevesinde Türk Ulus Kimliği İnşası ve 'Arap İhaneti' ', Divan, C. 17, S. 32, (2012/1), s. 169-188.

; “İttihatçılar ve Şerif Hüseyin: Mekke İsyanının Nedenleri Üzerine Bir Değerlendirme", Tarih ve Toplum Yeni Yaklaşımlar, S. 16, (Yaz 2013), s. 41-57.

ÇOLAK, Mustafa; Alman Imparatorluğu’nun Doğu Siyaseti Çerçevesinde Kafkasya Politikası (1914-1918), Türk Tarih Kurumu Yayınları, Ankara 2006.

DONOHOE, M. H.; İngiltere'nin İran/Azerbaycan Seferi 1918, Çev., Cengiz İ. Çay, Tarih ve Kuram Yayınları, İstanbul 2016.

ERICKSON, Edward J.; Size Ölmeyi Emrediyorum! Birinci Dünya Savaşı'nda Osmanlı Ordusu, Çev., Mehmet Tanju Akad, Kitap Yayınevi, İstanbul 2011.

ETTEHADIYYEH, Mansoureh; "İran Geçici Hükümeti”, Iran ve I. Dünya Savaşı Büyük Güçlerin Savaş Alanı, Edit., Touraj Atabaki, Çev., Gül Çağalı Güven, Tarih Vakfı Yurt Yayınları, İstanbul 2010, s. 9-28.

FALKENHAYN, Eric von; Birinci Dünya Savaşı ’nda Almanya, Çev., Kurmay Yarbay Bursalı Mehmet Nihat, Yay., Hz., Faruk Yılmaz, İz Yayınc1lık, İstanbul 2012. 
GOLTZ, Colmar Von Der; 20. Yüzyılın Başlarında Osmanlı-Alman İlişkileri "Golç Paşa'nın Hâtıratı’, Çev., E. Kay. Salih Mayakuşu, Yay., Hz., Faruk Yılmaz, İz Yayıncillk, İstanbul 2012.

Hafız Hakkı Paşa'nın Sarıkamış Günlüğü, Yay., Murat Bardakçı, Türkiye İş Bankası Kültür Yayınları, İstanbul 2016.

Irak Cephesi'nden Burma'ya Savaşın ve Esaretin Günlüğü, Taşköprülü Mehmed Efendi, Haz., Mesut Uyar-Ahmet Özcan, Türkiye İş Bankası Yayınları, İstanbul 2015.

KARABEKİR, Kâzım; I. Dünya Savaşı Anıları, Yay., Hz., Ziver Öktem, Yapı Kredi Yayınları, İstanbul 2018.

KARACA, Taha Niyazi; Sinırları Çizen Kadın Ingiliz Casus Gertrude Bell, Kronik Kitap, İstanbul 2018.

KARATAŞ, Kenan; Gertrude Bell İsyan, En Kitap Yayınları, İstanbul 2018.

KARPAT, Kemal; Osmanlı'dan Günümüze Ortadoğu'da Millet, Milliyet, Milliyetçilik, Çev., Recep Boztemur, Timaş Yayınları, İstanbul 2011.

KAŞIYUĞUN, Ali; Osmanlı Devleti'nin I. Dünya Savaşı'na Girişi, Yeditepe Yayınevi, İstanbul 2015.

KAYALI, Hasan; Jön Türkler ve Araplar, Osmanlıcıllk, Erken Arap Milliyetçiliği ve Íslamcılık 1908-1918), Çev., Türkan Yöney, Tarih Vakfi Yurt Yayınları, İstanbul 2003.

KOLOĞLU, Orhan; Curnalcilikten Teşkilat-ı Mahsusa'ya, Kırmızı Kedi Yayınevi, İstanbul 2017.

KÖSE, İsmail; İngiliz Arşiv Belgelerinde Arap İsyanı, Kronik Kitap, İstanbul 2018. ; Büyük Oyun'un Küçük Aktörü Şerif Hüseyin, Kronik Kitap, İstanbul 2018.

KRESS, von; Son Haçl Seferi Kuma Gömülen Imparatorluk, Çev., Tahir Balaban, Yeditepe Yayınevi, İstanbul 2007.

Lieutenant Colonel P. T. Crowley British Army, "Operational Lessons of the Mesopotamia Campaign, 1914-1918”, Defence Studies, Vol., 4, No., 3, (Autumn 2004), s. 335-360.

MCMEEKIN, Sean; I. Dünya Savaşı'nda Rusya'nın Rolü, Çev., Nurettin Elhüseyni, Yapı Kredi Yayınları, İstanbul 2013.

MÜHLMAN, Carl; Imparatorluğun Sonu 1914, Çev. Kadir Kon, Timaş Yayınları, İstanbul 2009.

POMIANKOWSKI, Joseph; Osmanlı Imparatorluğunun Çöküşü, Ter., Kemal Turan, Kayıhan Yayınları, İstanbul 2014.

POPPLEWELL, Richard; "British intelligence in Mesopotamia 1914-1916”, Intelligence and National Security, 5:2, (1990), s. 139-172.

Röportaj: “'Osmanlı Savaşı Neden Kaybetti?’, Atlas Tarih, Dosya Editörü: Tuncay Y1lmazer, S. 56, (Aralık 2018-Ocak 2019), s. 90-107.

Rumbeyoğlu Fahreddîn-Mehmed Nâbî, “Osmanlı Devleti’nin Son Yullarında Dış Politika Meseleleri IV: Muhammere', Tarih Okulu Dergisi, Aktaran., Ünal Taşkın, XIX (7), (Eylül 2014), s. 837-841. 
SABİS, Ali İhsan; Harp Hatıralarım Birinci Cihan Harbi, C.1, Nehir Yayınları, İstanbul 1990. İstanbul 1991.

; Harp Hatıralarım Birinci Cihan Harbi, C.4, Nehir Yayınları,

SAKİN, Serdar; “Ordu Lojistik Sisteminin Önemi Açısından Kut'ül-Amare Savaşı ve Resulayn-Musul Menzil Hattı”, SBArD, (Eylül 2009), s. 13-25.

SANDERS, Liman von; Türkiye'de Beş Sene, Çev., Osmanlı Genelkurmayı Askeri Tarih Encümeni Tercüme Heyeti, Yay., Haz., Muzaffer Albayrak, Yeditepe Yayınları, İstanbul 2013.

SARISAMAN, Sadık; “'Ömer Naci Bey Müfrezesi”, Ankara Üniversitesi Türk Inkılâp Tarihi Enstitüsü Dergisi Atatürk Yolu, S. 16, (1997), s. 501-513.

; "Birinci Dünya Savaşı Sırasında İran Elçiliğimiz İle İrtibatlı Bazı Teşkilat-1 Mahsusa Faaliyetleri’, OTAM, 7, (1996), s. 209-217.

SLUGLETT, Peter; "An improvement on colonialism? The 'A' mandates and their legacy in the Middle East', International Affairs, 90:2, (2014), s. 413-427.

SONAT, Ramazan; “'El Aneze Aşireti Ekseninde Birinci Dünya Savaşı’nın Gölgesinde DevletAşiret İlişkisi ve Yansımaları Üzerine Bir Tarih Kritiği”, History Studies International Journal of History, Vol., 10, Issue., 4, (June 2018), s. 167-187.

; “Tahran Sefiri Asım Bey'in Raporları Doğrultusunda Birinci Dünya Savaşı Sırasında İran'daki Rus Askerî Varlığı Üzerine Bir İnceleme',, Osmanlı Mirası Araştırmaları Dergisi, C. 5, S. 18, (Kasım 2018), s. 179-191.

; “'İki Farklı Hükümet İki Farklı Yaklaşım: İngiltere’nin Birinci Dünya Savaşı Sırasında Mezopotamya Harekâtının Şekillenmesinde Londra ve Delhi’nin Rolü ve Kut'ül Amâre Meselesine Yönelik Yeni Yaklaşımlar', Çanakkale Araştırmaları Türk Yıllığı, Yı1 17, S. 26, (Bahar 2019), s. 71-84.

SOY, H. Bayram; '“Birinci Dünya Savaşı Öncesinde 'Orta Doğu'da' Alman-İngiliz Mücadelesi”, Türkiye Günlüğ̈̈, S. 81, (Yaz 2005), s. 104-117.

TAŞKIRAN, Cemalettin; Ana Ben Ölmedim, Birinci Dünya Savaşı'nda Türk Esirleri, Türkiye İş Bankası Kültür Yayınları, İstanbul 2015.

ULRICHSEN, Kristian Coates; "The British Occupation of Mesopotamia, 1914-1922", The Journal of Strategic Studies, Vol., 30, No., 2, (April 2007), s. 349-377.

UYAR, Mesut; "Ottoman Arap Officers between Nationalism and Loyalty during the First World War', War in History, 20(4), (2013), s. 526-544.

-Edward J. Erickson, Osmanlı Askeri Tarihi, İş Bankası Kültür Yayınları, İstanbul 2017.

ÜÇÜNCÜ, Uğur; “Birinci Dünya Savaşı'nda Mustafa Kemal Paşa'nın Osmanlı Ordusu'ndaki Alman Subaylarına Bakışı", OTAM, 39, (Bahar 2016), s. 241-267.

ÜZEN, İsmet; "Birinci Dünya Savaşında Sina ve Filistin Cephesindeki Türk-Alman Subayların Çeşitli Konularda Çatışması (1914-1918)', Karatekin Edebiyat Fakültesi Dergisi, C. 3, S. 3, (2014), s. 77-100. 
WHITECOTTON, Victoria; "The Iraqi Mandate: An Examination of the Relationship between Britain and Iraq in the Aftermath of the First World War, Saber and Scroll, Vol., 1, Issue., 3, Article 7, (Fall 2012), s. 65-75.

YILDIZ, Gültekin; "Birleşik Harekât Tecrübesi Olarak Cihan Harbinde Türk-Alman Askerî İttifak1", 1914'ten 2014'e 100'üncü Yılında Birinci Dünya Savaşı'nı Anlamak, Harp Akademileri Komutanlığı Stratejik Araştırmalar Enstitüsü, İstanbul 2014, s. 191-202.

YÜCE, Samet; Britanya'nın Ortadoğu Politikası ve Gertrude Bell, Nizamiye Akademi, İstanbul 2018.

YÜKSEL, Çağdaş; Birinci Dünya Savaşı Yıllarında Teşkilat-ı Mahsusa, Pamukkale Üniversitesi Sosyal Bilimler Enstitüsü Basılmamış Doktora Tezi, Denizli 2019.

\section{İnteraktif Kaynaklar}

https://www.britannica.com/event/World-War-I/Killed-wounded-and-missing. Erişim Tarihi: 25.02.2019

http://www.uwosh.edu/faculty_staff/henson/188/WWI_Casualties\%20and\%20Deaths\%2 0\%20PBS.html. Erişim Tarihi: 25.02.2019 